\title{
Fenomen polityzacji buddyzmu w XXI wieku. Buddyzm jako narzędzie budowania ideowej tożsamości narodu w Birmie (Mjanma) i na Sri Lance oraz realizowania polityki zagranicznej w kontekście współzawodnictwa indyjsko-chińskiego w Azji
}

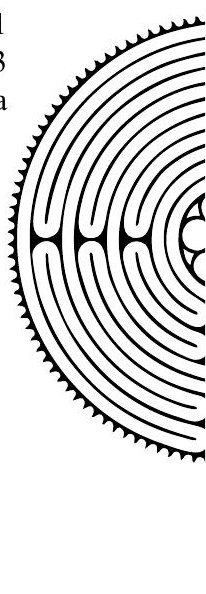

\section{Piotr Kłodkowski}

Instytut Badań nad Cywilizacjami

Wyższa Szkoła Informatyki i Zarządzania w Rzeszowie

\section{Abstract \\ The Phenomenon of Politicisation of Buddhism in the $21^{\text {st }}$ Century}

The text focuses on the issues of political interpretation of Buddhism in Myanmar and Sri Lanka, as well as on its role as an element of diplomatic soft power in bilateral Indo-Chinese relationship. The author analyses the problems of self-immolation, non-violence vs violence policies and national identity building in the context of re-defining Buddhism in the political realities of selected Asian countries.

Key words: Political Buddhism, violence, Myanmar (Burma), Sri Lanka, Dalai Lama, Buddhist Congregation

Słowa kluczowe: buddyzm polityczny, przemoc, Mjanma (Birma), Sri Lanka, Dalajlama, Kongregacja buddyjska

Buddyzm, w przeciwieństwie do wielu światowych tradycji religijnych, takich jak islam czy hinduizm, bardzo rzadko kojarzony był z bezpośrednim zaangażowaniem w bieżącą sferę polityczną, aczkolwiek nie sposób pominąć funkcjonujących zaleceń dotyczących dobrego i sprawiedliwego zarządzania (governance), które stanowią część przesłania doktryny. Sama jej interpretacja może mieć jednak zabarwienie polityczne, zwłaszcza że na przykład zjawisko protestu przeciw postrzeganym aktom niesprawiedliwości w sferze społecznej generuje bezpośrednie implikacje w świecie 
polityki. Reakcja na postrzeganą „niesprawiedliwość” może być dwojaka: albo - zgodnie z tradycją obecną w kanonie buddyjskim - jest samopoświęceniem, nierzadko prowadzącym do śmierci, albo też - i to głównie w kontekście zjawisk charakterystycznych dla XX wieku - staje się atakiem najpierw werbalnym, a następnie fizycznym na tych, których definiuje się jako „sprawców niesprawiedliwości” bądź „zagrożenia wspólnoty lub narodu”. Kolejnym rodzajem politycznego zaangażowania buddyzmu jest jego uprzedmiotowienie bądź instrumentalizacja przez władze państwowe, i to niekoniecznie o autorytarnym zabarwieniu. Chodzi tutaj o znany już wcześniej fenomen propagowania odpowiednio interpretowanych wartości buddyjskich w relacjach międzypaństwowych. Buddyzm stanowi część dyplomatycznej soft power XXI wieku i służy przede wszystkim jako środek, a nie cel sam w sobie, do budowania sieci wpływów w wybranych regionach globu. W kontekście azjatyckim ten ostatni przykład ma zastosowanie w polityce dwóch najludniejszych państw świata: Chin oraz Indii.

Polityzacja buddyzmu nie jest w żadnej mierze zjawiskiem świeżej daty, niemniej jednak gwałtowna radykalizacja i konfrontacyjność działań wybranych organizacji buddyjskich, mających dodatkowo globalny oddźwięk w mediach, wskazuje na pewną nową jakość procesu polityzacji, zwłaszcza po roku 2012 roku. Możemy to roboczo zdefiniować - korzystając ze wzorców Huntingtona - jako „trzecią falę" polityzacji współczesnego buddyzmu, przy czym pierwsza z nich przypadałaby na okres kolonizacji europejskiej, druga na lata powojenne, trzecia na drugą dekadę XXI wieku ${ }^{1}$. Nie sposób obecnie przewidzieć, jakie będą konsekwencje „trzeciej fali” w procesie budowania tożsamości kulturowej wybranych państw. Podobnie za novum trudno uznać polityzację buddyzmu na arenie międzynarodowej, bowiem jego początków doszukiwać się można już w inicjatywach cesarza Aśoki w III wieku przed Chrystusem. Chodzi tutaj bardziej o skalę działań, ich zasięg geograficzny oraz metody promowania własnych koncepcji politycznych z wykorzystaniem międzynarodowych kanałów informacyjnych. Tego typu inicjatywy można uznać znowu za nową jakość w procesie polityzacji buddyzmu w wymiarze międzynarodowym. Od razu wyjaśnijmy w tym miejscu, że niełatwo oszacować skuteczność takich działań, ponieważ ich konsekwencje bywają dostrzegalne w relatywnie długich okresach, obecnie mierzonych na szczęście raczej dekadami aniżeli wiekami.

\section{Fenomen polityzacji buddyzmu w kontekście samoofiary}

Możliwości interpretacji zasad etycznych oraz postępowania świeckich i członków zakonu (sangha) w szerokim kontekście politycznym może być bardzo wiele, zaś sama interpretacja zależałaby od lokalnych uwarunkowań oraz intencji tego, kto owej interpretacji dokonuje. Jedna $\mathrm{z}$ takich możliwości miałaby z pewnością zastosowanie przy fenomenie samoofiary. Zasada poświęcenia samego siebie dla niesienia pomocy innym istotom żywym jest obecna w przesłaniu Dżatak i może mieć

${ }^{1}$ S. Huntington, Trzecia fala demokratyzacji, thum. A. Dziurdzik, Warszawa 2009. 
jak najbardziej polityczną interpretację. Tekst $O$ tygrysicy, w którym książę Sattwa składa ofiarę z części własnego ciała, aby ratować samicę i jej małe od śmierci głodowej, a także utwór Śibi Dżataka, w którym podobnego czynu samopoświęcenia dokonuje na rzecz jastrzębia książę Śibi, niosą bardzo wyraźne przesłanie o wartości etycznej ofiary, realizowanej - co warto podkreślić - bez szkody fizycznej na osobach trzecich ${ }^{2}$. Z kolei 23 rozdział Sutry Lotusowej wskazuje na motyw samospalenia boddhisattwy Sarvarupasamdarsany, przy czym ostatecznym celem ofiary jest podkreślenie nieprzemijającej substancji buddyjskiej dharmy. ${ }^{3}$ Tego typu czyn można interpretować już bardzo dosłownie. Będzie on przedstawiany jako najbardziej szlachetna ofiara na rzecz innych istot oraz jako memento przesłania buddyzmu, ale również - i tutaj motywacja ofiarnika będzie dotykała konkretnych wydarzeń - jako protest przeciw postrzeganej niesprawiedliwości. Jego adresatem jest najczęściej albo konkretny człowiek, książę bądź król, albo określona grupa osób zaangażowanych w proces rządzenia, ocenianego krytycznie. Samospalenie ma w takiej sytuacji wzbudzić wyrzuty sumienia adresata i zmusić go do zmiany swego zachowania, a dodatkowo powinno skłonić do właściwego działania naocznych obserwatorów zdarzenia. Prawdopodobnie najwięcej przypadków samospalenia było wśród buddystów w Chinach lub zostały tam najlepiej udokumentowane. Najwcześniejsze, a przynajmniej najwcześniej zarejestrowane pochodzi z roku 396 n.e. i dotyczy mnicha Fayu, który miał występować przeciw „bezprawnemu księciu” Yao $\mathrm{Xu}^{4}$. James S. Benn zwraca uwagę, że między wiekiem IV a XX najwięcej samospaleń dokonano w czasach prześladowań buddyzmu w Państwie Środka, tak więc miały one charakter moralnego protestu w stosunku do ówczesnej władzy ${ }^{5}$. Z kolei w XX stuleciu i na początku XXI wieku najbardziej znane akty samospalenia wśród wyznawców buddyzmu dokonały się w Wietnamie przed okresem zjednoczenia i wśród Tybetańczyków żyjących w ChRL lub na uchodźstwie. Symbolem radykalizmu etycznego w okresie interwencji amerykańskiej w Wietnamie został mnich Thich Quang Duc, który dokonał publicznego samospalenia 11 czerwca 1963 roku w proteście przeciw polityce prezydenta Diema (skądinąd katolika) - zdaniem wspólnoty zakonnej - dyskryminującego swoich współobywateli buddystów. Zdjęcie tragicznego wydarzenia, autorstwa Malcolma Browne’a, laureata Nagrody Pulitzera, obiegło cały świat, a to z kolei spowodowało międzynarodową presję na prezydenta Diema, aby radykalnie zmienił swoją politykę. Wielu kolejnych mnichów poszło w ślady Thich Quang Duca i ostatecznie armia usunęła prezydenta, po czym sam Diem został

2 Por. R. Wolf, The Popular Encyclopedia of World Religions, Harvest House Publishers 2007, s. 65-106; R. Linossier, The Mythology of Buddhism in India [w:] Asiatic Mythology, New Delhi-Madras 1994, s. 89.

${ }^{3}$ The Lotus Sutra, A Contemporary Translation of a Buddhist Classic, transl. and introduction G. Reeves, rozdz. 23: Previous Lives of Medicine King Bodhisattva, New York 2014.

${ }^{4}$ Por. J.S. Benn, Burning for the Buddha: Self-immolation in Chinese Buddhism, Honolulu 2007, s. 33-34.

5 J.B. Benn stawia tezę, że samo zjawisko samospalenia (self-immolation, auto-cremation) jest przede wszystkim związane z buddyzmem w Chinach (aczkolwiek wskazuje na pojedyncze przypadki w Indiach. Duża liczba samospaleń w Indiach nie miała prawdopodobnie związku z buddyzmem i była częścią kultury hinduistycznej. Ibidem, s. 11. 
zamordowany 2 listopada 1963 roku$^{6}$. W tym konkretnym przypadku ofiara samospalenia spełniła swój polityczny cel, i to zarówno jeżeli chodzi o ukaranie sprawcy prześladowania, jak i reakcję opinii publicznej w kraju i za granicą.

Najbardziej tragiczne, a zarazem mocno nagłaśniane medialnie wydarzenia w ciągu ostatniej dekady dotyczyły Tybetańczyków. Akty samospalenia buddyjskich mnichów były interpretowane jako protest przeciw brutalnym działaniom władz chińskich i stopniowemu procesowi sinizacji samego Tybetu w granicach ChRL. Od roku 2008 co najmniej 150 osób dokonało samospalenia, przy czym przynajmniej 40 zmarło $^{7}$. W swoim publicznym wystąpieniu Kirti Rinpoche, zaufany Dalajlamy XIV, oświadczył, że

[...] samospalenia nie były organizowane, ani też inspirowane przez diasporę tybetańską [rząd tybetański na uchodźstwie - P.K.]. Są działaniami poszczególnych jednostek, pozbawionymi elementu egoizmu, zaś ich akty samospalenia służą całej wspólnocie. Chociaż diaspora w żaden sposób nie zachęca do takich działań, to z pewnością mają one wartość z punktu widzenia doktryny buddyzmu ${ }^{8}$.

Kirti Rinpoche w swoich oficjalnych enuncjacjach dla mediów europejskich odnosił się do oskarżeń rządu ChRL, który wskazywał personalnie na Dalajlamę jako inspiratora, bezpośredniego lub pośredniego, całej serii samospaleń. Duchowy zwierzchnik wspólnoty tybetańskiej w 2013 roku oświadczył oficjalnie, że w praktyce niewielka jest skuteczność takiej ofiary jako taktyki, w domyśle politycznej. Wyjaśnił też, i to wielokrotnie, że ma niewielki wpływ na kandydatów do samospalenia i że „czynią to z własnej, nieprzymuszonej woli”. Dalajlama wyrażał publicznie swój głęboki smutek z powodu śmierci współbraci w wierze, chwaląc jednakże ich odwagę i poświęcenie. Tego typu sformułowania pozytywnie wartościują publiczny czyn samobójczy, który dokonywany jest w imieniu wspólnoty i zyskuje akceptację innych współwyznawców. Polityczną już stricte deklaracją, w ślad za sformułowaniami Dalajlamy, została oficjalna galeria zdjęć męczenników umieszczona w pobliżu świątyni buddyjskiej w dzielnicy tybetańskiej (Tibetan Village) w New Delhi. Akty samospalenia zostały zakwalifikowane jako element doktryny non-violence w walce przeciw rządowi ChRL, przy czym ich faktyczna skuteczność polityczna jest nadal przedmiotem debaty zarówno wśród samych Tybetańczyków, jak i polityków oraz obserwatorów państw trzecich?

${ }^{6}$ Por. The Prototype of Auto-cremation as Political Protest - The Death of Thich Quang Duc [w:] Sacred Suicide, J.L. Lewis, C.M. Cusack (red.), Burlington 2014, s. 186 i n.

${ }^{7}$ Dane za: T. Woeser, Tibet on Fire: Self-immolations against Chinese Rule, New York 2016. Warto dodać, że autorka, urodzona w Lhasie w 1966 r., jest również związana z kulturą Chin kontynentalnych i publikuje swoje teksty także w języku chińskim. Podkreśla, że jest w jednej czwartej Chinką (Han), a w trzech czwartych Tybetanką. Była wielokrotnie karana za artykuły na temat sytuacji w Tybecie.

${ }^{8}$ Całość wypowiedzi i dane na temat wydarzeń w Tybecie i poza jego granicami relacjonowana była przez „The Economist”, http://www.economist.com/blogs/erasmus/2013/03/buddhism-and-self-immolation [dostęp: 22.11.2015].

${ }_{9}$ Publiczna galeria zdjęć, ofiar samopodpaleń w Tibetan Village nie była przedmiotem publicznej krytyki rządu indyjskiego, i to zarówno na poziomie centralnym, jak i lokalnym. O ile New Delhi z małym entuzjazmem akceptuje publiczne polityczne oświadczenia rządu tybetańskiego na uchodźctwie, o tyle w praktyce diaspora tybetańska, szacowana na około 100 tys. osób, funkcjonuje bez przeszkód. Tibetan 
Te działania, które charakteryzują się skrajnym poświęceniem fizycznym po to, aby dać świadectwo postrzeganej i krytykowanej niesprawiedliwości, odzwierciedlają coraz mocniejsze zaangażowanie wspólnoty buddyjskiej w spór polityczny, który ma obecnie charakter ponadpaństwowy. Nie dotyczy on wyłącznie relacji między Tybetańczykami i Chińczykami (grupa etniczna Han), ale ma ścisły związek z Indiami, gdzie rezyduje zwierzchnik tybetańskiego buddyzmu oraz administracja rządu na uchodźctwie. Dodatkowo działania diaspory tybetańskiej mają szeroki oddźwięk zarówno w Europie, jak i Stanach Zjednoczonych. Jednak najbardziej znacząca w kontekście polityzacji buddyzmu jest wysoka ocena etyczna samych czynów samospalenia, których wyłącznymi ofiarami stają się ich sprawcy, bez udziału (tzn. śmierci lub fizycznej krzywdy) osób trzecich ${ }^{10}$. Ten element nowej, dość specyficznej interpretacji doktryny non-violence, ilustruje fenomen silnej polityzacji buddyzmu, przy czym owa polityzacja niekoniecznie będzie postrzegana jako niezgodna z samą doktryną religijną.

\section{Ideologia jedności religijno-etnicznej. Przykłady Birmy (Mjanma) i Sri Lanki}

Zupełnie odmiennym przykładem polityzacji będzie działanie ugrupowań buddyjskich w Birmie i na Sri Lance, które przykuło znaczną uwagę zarówno mediów międzynarodowych w ciągu ostatniego pięciolecia, jak i organizacji pozarządowych zajmujących się kwestiami praw człowieka. Globalnym symbolem przemocy usprawiedliwianej przesłaniem religijnym został birmański mnich Ashin Wirathu, bohater tak zwanej cover story magazynu „Time” z 2013 roku. Zaprezentowano go jako „twarz buddyjskiego terroru” (The Face of Buddhist Terror), który skierowany jest przeciw lokalnej mniejszości muzułmańskiej, stanowiącej około 5\% całości populacji ${ }^{11}$. Chodzi tu głównie o społeczność Rohingja, zamieszkującą zachodnią część kraju i uznawaną zarówno przez poszczególne agendy Narodów Zjednoczonych, jak i przez

Village, podobnie jak i McLeod Ganj, gdzie rezyduje Dalajlama, są tego dobrym przykładem. Mało prawdopodobne, aby sytuacja uległa zmianie po przejęciu władzy przez BJP. Wypowiedzi Dalajlamy i dyskusja na temat implikacji samospalenia kolejnych mnichów nastąpiły podczas spotkań z szefami misji dyplomatycznych UE w New Delhi w latach 2012 i 2013. Ze względu na osobisty autorytet Tenzina Gyatso, czyli Dalajlamy XIV w świecie i powszechną admirację wśród wiernych używając jego formalnego tytułu stosuję w nazwie dużą literę, natomiast formalny tytuł jego poprzedników „dalajlama” pisany jest małą literą.

${ }^{10}$ Akty samobójcze były podejmowane przez nominalnych wyznawców innych religii, przy czym ich ocena etyczna w żadnym razie nie była zgodna wśród członków wspólnot muzułmańskiej i hinduistycznej. Ataki samobójcze Al-Kaidy czy ISIS były w zasadzie kierowane ku postronnym, często przypadkowym ofiarom, zresztą podobnie jak ataki Tygrysów Tamilskich. To fundamentalna różnica, która eliminuje wszelkie podobieństwa do działań buddystów tybetańskich czy wcześniej wietnamskich. Por. cytowaną wcześniej pozycję Sacred Suicide...

${ }^{11}$ H. Beech, The Face of Buddhist Terror, „Time” magazine, 1 July 2013. Według oficjalnego spisu ludności sporządzonego w 2014 r. liczba wyznawców islamu w Birmie wynosi 4,3\%. Por. Department of Population Ministry of Labour, Immigration and Population MYANMAR (July 2016), The 2014 Myanmar Population and Housing Census, Census Report Volume 2-C, Department of Population Ministry of Labour, Immigration and Population MYANMAR, s. 12-15. 
liczne organizacje pozarządowe za jedną z najbardziej prześladowanych wspólnot etniczno-religijnych na świecie ${ }^{12}$. Wirathu jest zwolennikiem radykalnej tezy, że Birma powinna być krajem buddyjskim, bez jakichkolwiek odniesień do tradycji islamu. Swoje przesłanie uzasadnia, powołując się na historię Azji Południowej i Południowo-Wschodniej: niegdyś buddyjskie ziemie w Afganistanie, Pakistanie, Malezji czy Indonezji obecnie znajdują się we władaniu cywilizacji islamu, stąd też jego apel o „powstrzymanie pochodu muzułmanów". W swoich przemówieniach używa języka politycznego i religijnego ekstremizmu: „Muzułmanie rozmnażają się bardzo szybko, porywają i gwałcą nasze kobiety; zamierzają okupować nasz kraj. Nie pozwolę im na to. Musimy sprawić, aby Birma pozostała buddyjska"13. Ashin Wirathu został już aresztowany w 2003 roku i osadzony w więzieniu do roku 2010 za nawoływanie do nienawiści międzyreligijnej, jednak po rozpoczęciu procesu transformacji w kraju, tj. po przekazaniu formalnie władzy przez rząd wojskowy w 2011 roku, uzyskał wsparcie dla swoich działań, między innymi od prezydenta Thein Seina. Od tego czasu Wirathu buduje coraz silniejszą pozycję w państwie, do jego zwolenników zalicza się około 2500 buddyjskich mnichów, stoi też na czele ruchu 969 (symbolizującego triratnę, trzy klejnoty Buddy), który otwarcie nawołuje, aby buddyści nigdy nie rozwijali ani nie utrzymywali związków z przedstawicielami pozostałych wyznan, innymi słowy: aby wspierali wyłącznie własną wspólnotę religijno-etniczną. Głoszone przez organizację hasła są proste i zrozumiałe, jak na przykład: „troska o własną religię i własną rasę jest ważniejsza aniżeli sama demokracja”, aczkolwiek nie zawsze akceptowalne przez każdego Birmańczyka. Wirathu nawołuje do blokowania mieszanych małżeństw i bojkotu przedsiębiorstw prowadzonych przez muzułmanów. Działania w stosunku do mniejszości nie ograniczają się do radykalnych sloganów i niezbyt skomplikowanego przesłania „Birma dla buddystów”. Mowa nienawiści skutkuje fizycznymi atakami i przelewem krwi. Jedno z najlepiej udokumentowanych krwawych wydarzeń - według Human Rights Watch - nastąpiło w 2012 roku w wysuniętych na zachodzie kraju wioskach zamieszkanych przez Rohingjów. Uzbrojeni w maczety wyznawcy buddyzmu zamordowali około 70 muzułmanów w czasie trwającego cały dzień pogromu. W następnym roku w marcu doszło do kolejnych pogromów w miejscowości Meiktila, gdzie całe dzielnice zostały zniszczone przez wyznawców buddyzmu, rzekomo po informacji o śmierci buddyjskiego mnicha. Bilans zabitych to 40 muzułmanów i 2 buddystów ${ }^{14}$. Pogromy antymuzułmań-

${ }^{12}$ Rohingja wywodzą się ze stanu Arakan (obecnie Rakhine) położonym na zachodnim wybrzeżu kraju. Por. A. Simpson, Language and National Identity in Asia, Oxford 2007, s. 267. Ich liczba wynosi prawdopodobnie 1,3 miliona w całym państwie (2014 - por. spis ludności, przyp.10), aczkolwiek z powodu wymuszonej migracji może mieć ona obecnie inną wielkość. Bardzo często kolejne rządy birmańskie stawiały tezę, iż w rzeczywistości Rohingja są społecznością migrantów, którzy przybyli do Arakanu dopiero po uzyskaniu niepodległości przez Birmę w $1948 \mathrm{r}$. (pierwsza fala migracji) oraz po $1971 \mathrm{r}$. (druga fala), czyli po powstaniu niepodległego Bangladeszu, a więc z terytorium, z którego mieli jakoby się wywodzić. Por. International Crisis Group, Report 261/ Asia, 22 October 2014, Myanmar: The Politics of Rakhine State.

${ }^{13}$ Ibidem. Wypowiedzi Wirathu za tekstem publikowanym w „Time” z lipca $2013 \mathrm{r}$.

${ }^{14}$ Dokładna relacja z serii pogromów została umieszczona w raportach Human Rights Watch. Por. „All You Can Do is Pray”. Crimes against Humanity and Ethnic Cleansing of Rohingya Muslims in Burma's Arakan State, April 22, 2013, https://www.hrw.org/report/2013/04/22/all-you-can-do-pray/ 
skie przyczyniły się do masowego exodusu wspólnoty Rohingjów, głównie na obszar Bangladeszu, ale również do Indii. Filozofia przemocy Ashina Wirathu została wielokrotnie potępiona przez innych wyznawców, aczkolwiek politycy birmańscy są podzieleni w ocenie jego działań. Przykładowo, przeor klasztoru Myawaddy Sayadaw w Mandalaj, Arriya Wuttha Bewuntha stwierdził, że hasła głoszone przez Wirathu nie mają nic wspólnego z nauczaniem Buddy, podobne niezwykle krytyczne sformułowania zostały przedstawione przez innych mnichów w całym państwie ${ }^{15}$. Z kolei laureatka Pokojowej Nagrody Nobla Aung San Suu Kyi wstrzymała się z publiczną krytyką działań Wirathu z obawy o utratę poparcia wśród części swoich bardziej radykalnych wyborców.

Aktywność Wirathu i ruchu 969, mocno nagłośniona w międzynarodowej przestrzeni medialnej i politycznej, stanowi nową jakość, jeżeli uwzględni się jednowymiarowy przekaz skrajnych treści ideologicznych, ich oddźwięk poza granicami kraju, a także dynamikę brutalizacji działań oraz samą logistykę krwawych pogromów, ale nie jest bynajmniej początkiem zjawiska polityzacji buddyzmu w Birmie czy może raczej - polityzacji samej wspólnoty mnichów. Sposób organizacji polityki w kontekście nauki buddyjskiej znany już był w XIX wieku i opierał się na jeszcze wcześniejszym przekazie. Matthew J. Walton przywołuje postać królewskiego doradcy U Hpo Hlainga, autora podręcznika politycznych reguł dla władcy Rajadhammasangaha (1878), w którym łączy tradycję buddyjską ze współczesnymi mu europejskimi koncepcjami zarządzania państwem. Bardzo interesujący jest fragment dotyczący właściwego podejmowania decyzji. Omylność jednostki przeciwstawiana jest nieomylności wspólnoty, co można łatwo interpretować jako wyższość zgromadzenia nad rządami autorytarnymi monarchy, ale też nie można wykluczyć innego odczytania fragmentu (nawet w zupełnie innym kontekście historycznym), a mianowicie konieczności budowania spójnych ideowo ugrupowań, które są w stanie wskazać właściwą ścieżkę postępowania dla wiernych. U Hpo Hlaing pisał:

Jeżeli pewna grupa osób zbierze się razem dla podjęcia działania, nie może być wątpliwości, że nie będą postępowali według nieprawości (agati). W takim zgromadzeniu, nawet jeżeli jeden człowiek nie wie [jak czynić - P.K.], inny będzie taką wiedzę posiadał, kiedy jeden odczuwa nienawiść, inny jest jej pozbawiony, kiedy jeden jest pełen gniewu, inny jest spokojny. Kiedy [zatem - P.K.] ludzie zgromadzą się wspólnie i zachowują się solidarnie, to nie ma powodu do obawy i niepokoju. $Z$ tych też przyczyn musimy stwierdzić, że gdy pewna liczba ludzi przedstawia sprawy w zgromadzeniu, to niemożliwym jest, aby podążali drogami czterech nieprawości (agati) ${ }^{16}$.

crimes-against-humanity-and-ethnic-cleansing-rohingya-muslims [dostęp: 7.10.2015]. Mimo staranności przedstawicieli HRG przy zbieraniu danych o pogromach możemy założyć, że liczba ofiar pogromów może być znacznie wyższa; zresztą trudność w oszacowaniu liczby zabitych i rannych charakteryzuje każde tego typu tragiczne wydarzenie.

${ }^{15}$ Wypowiedzi mnichów, w tym Arriya Wuttha Bewunthy, publicznie krytykujących Wirathu za: K. Hodal, Buddhist Monk uses Racism and Rumours to Spread Hatred in Burma, „The Guardian”, 18 April 2013.

${ }^{16}$ Hpo Hlaing, Mingyi U Iaw, Rajadhammasangaha, transl. L.E. Bagshawe from the biographical preface and edition made by Maung Htin (U Htin Fatt), Rangoon 1979, s.174. Całość tekstu dostępna jest również w wersji elektronicznej: http://www.ibiblio.org/obl/docs/THE_RAJADHAMMASANGAHA. pdf [dostęp: 7.10.2015]. 
Alicia Turner podkreśla, że U Hpo Hlaing przyczynił się do aktywizacji świeckich wyznawców buddyzmu, zwłaszcza po upadku monarchii w 1889 roku, którzy stopniowo budowali polityczny system partii i zgromadzeń, formalnie odwołujący się do przesłania buddyzmu. Jej zdaniem, ówczesna polityzacja religii nie oznaczała jednakże tworzenia jakiejkolwiek koncepcji jedności narodowo-wyznaniowej, a raczej wzmocnienie samej tożsamości buddyjskiej czy szerzej - ochrony dziedzictwa sāsana (czyli buddyzmu) przed wpływami zewnętrznymi ${ }^{17}$. Walton wskazuje jeszcze na inną postać, której publiczne wystąpienia i polityczne koncepcje miały swoje przełożenie na działania wspólnoty buddyjskiej kilkadziesiąt lat później. U Ottama (zm. 1939), wykształcony w Indiach buddyjski mnich, który miał okazję zapoznać się z metodami walki politycznej na subkontynencie, łączył już otwarcie kwestię wyznania $\mathrm{z}$ tożsamością narodową. Ian Harris uznaje go za pierwszego mnicha nacjonalistę w Birmie, który zdobył powszechne uznanie (He was the first prominent nationalist monk in Burma). U Ottama w swoim otwartym liście do brytyjskiego gubernatora („Craddock Go Home”) oskarża Brytyjczyków o sprowadzenie rdzennych mieszkańców Birmy do poziomu niewolników, przy czym istotną rolę w przedstawianym procesie społecznej i politycznej degeneracji odgrywa religia. U Ottama nie kryje swojego krytycyzmu w stosunku do chrześcijaństwa, które postrzega jako zagrożenie dla tradycji buddyjskich. Ciekawe jest też jego stanowisko wobec dyscypliny zakonnej. Lekceważy oficjalny nakaz powstrzymywania się mnichów od działalności politycznej, skądinąd wymuszony przez administrację brytyjską, usprawiedliwiając swoją aktywność słowami: „Sangha nie powinna ignorować cierpienia ludu" ${ }^{18}$. W jednym ze swoich publicznych przemówień stwierdza, że brytyjski rząd wręcz uniemożliwia dążenie wiernych do nirwany, co już łatwo interpretować jako wezwanie do czynnego oporu przeciw ówczesnej administracji kolonialnej ${ }^{19}$. Walton dokonuje dość intrygującej interpretacji jego wystąpienia, dopasowując go do sytuacji o kilkadziesiąt lat późniejszej:

U Ottama nie tylko potwierdził związek między sytuacją polityczną a moralną praktyką, ale zasugerował, że w pewnych okolicznościach, buddyści mogą poczuć się zmuszeni do czasowego zawieszenia swoich dążeń do osiągnięcia nirwany na rzecz bardziej naglącego zadania zapewnienia politycznej wolności. Odmiana tego typu argumentacji będzie później używana przez władze kraju, jak również przez mnichów powiązanych z nacjonalistycznymi ruchami po 2012 roku $^{20}$.

Birmańska sangha nie przestała się angażować politycznie również po uzyskaniu przez państwo niepodległości. Wojskowa dyktatura, sprawująca faktycznie władzę od 1962 do 2011 roku, nie odrzucała formalnie symboliki buddyjskiej, co więcej 2014.

${ }^{17}$ Por. A. Turner, Saving Buddhism: The Impermanence of Religion in Colonial Burma, Honolulu

${ }_{18}$ Por. I. Harris, Buddhism, Politics and Nationalism [w:] Buddhism in the Modern World, D. McMahan (red.), New York 2012.

19 Por. D.E. Smith, Religion and Politics in Burma, Princeton, NJ, 1965.

${ }^{20}$ M.J. Walton, Burmese Buddhist Politics, http://www.oxfordhandbooks.com/view/10.1093/oxfordhb/9780199935420.001.0001/oxfordhb-9780199935420-e-21\#oxfordhb-9780199935420-e-21-bibItem-25 [dostęp: 17.12.2016]. 
donacje na rzecz wybranych fundacji i świątyń dokonywane przez oficerów armii sugerowały, że to oni powinni być powszechnie uznawani za patronów tradycji buddyjskiej ${ }^{21}$. Buddyzm był i jest nadal postrzegany przez większość mieszkańców jako kulturowe spoiwo państwa zamieszkiwanego oficjalnie przez 135 grup etnicznych, przy czym Bamarowie stanowią około $70 \%$ populacji ${ }^{22}$. Wspólnota mnichów niekoniecznie przyjmowała taką narrację. Występowała kilkakrotnie przeciw dyktaturze wojskowej, przy czym najbardziej znaczące liczebnie protesty odbyły się w 1988 i 2007 roku. Naturalnie nie skupiały się wówczas na kwestii tożsamości religijno-narodowej, lecz na obronie podstawowych zasad demokracji i potępieniu przemocy stosowanej przez armię. Sama koncepcja „demokracji” została uznana za zgodną z nauką buddyjską, chociaż - jak głosił mnich Ashin Eindaga - powinna opierać się na właściwych fundamentach moralnych (taya), aby zyskać powszechną akcepta$\mathrm{cję̨}^{23}$. Napięcia między armią a sanghą miały także przełożenie na codzienny język czy nawet na specyficzne poczucie humoru. Twierdzono na przykład, że programy miejscowej telewizji mają wyłącznie dwa kolory: zielony i szafranowy, co naturalnie było nawiązaniem do kolorów mundurów wojskowych i szat mnichów, a więc dwóch najważniejszych aktorów na scenie politycznej. Z kolei sformułowanie thabeik hmauk, tłumaczone najczęściej jako „bojkot” i używane przykładowo w kontekście masowych demonstracji w 1988 roku, oznacza odwrócenie przez mnicha do góry dnem miski na jedzenie, uniemożliwiając tym samym zdobycie zasługi przez pobożnego świeckiego. Tego typu gesty mają swoją długą historię i nadal wpisują się w lokalną symbolikę polityczną.

Formalne złożenie władzy przez armię nie oznaczało w żaden sposób zakończenia miejscowych konfliktów etnicznych (mających także swój udział w sporach konfesyjnych) ani porzucenia przez sanghę działalności politycznej. Od roku 2012 nasilił się proces radykalizacji niektórych wspólnot mnichów, co zaowocowało nie tylko głoszeniem skrajnej antymuzułmańskiej ideologii, także powołaniem do życia organizacji lub partii, które w sposób systemowy planują implementację sugerowanych rozwiązań prawnych. Oprócz wspomnianego już ruchu 969 istotną rolę pełni tutaj Organizacja na rzecz Ochrony Rasy i Religii, znana pod birmańskim akronimem Ma Ba Tha. Jej członkami są zarówno zakonnicy, jak i świeccy, zaś jednym $\mathrm{z}$ celów, oprócz propagowania w mowie i piśmie tradycji buddyjskiej (aczkolwiek interpretowanej $\mathrm{w}$ duchu narodowo-konfesyjnym), jest implementacja przepisów prawa znacznie ograniczającego konwersję i małżeństwa międzywyznaniowe. Jak sugeruje Kyaw San Wai, radykalizm takich organizacji, jak Ma Ba Tha, ruch 969 czy symbolicznej już postaci Ashina Wirathu, wynika z kompleksu „oblężonej twierdzy” i powszechnego jakoby wśród birmańskich buddystów poczucia zagrożenia ze strony islamu, dynamicznie rozwijającego się w wielu częściach Azji. Kyaw San Wai

${ }^{21} \mathrm{Na}$ temat procesów polityzacji wspólnoty buddyjskiej we wczesnym okresie postniepodległościowym zob. M.E. Spiro, Buddhism and Society: A Great Tradition and its Burmese Vicissitudes, Berkeley 1982; M. Sarkisyanz, Buddhist Backgrounds of the Burmese Revolution, The Hague 1965; M.E. Mendelson, Sangha and State in Burma: A Study of Monastic Sectarianism and Leadership, Ithaca, NY, 1975.

22 Por. Department of Population Ministry of Labour, Immigration and Population MYANMAR (July 2016), s. 12-15.

${ }^{23}$ M.J. Walton, op.cit. 
powołuje się na milenarystyczną przepowiednię, niepopartą w oficjalnym kanonie, aczkolwiek popularną w ludowym przekazie, że buddyzm będzie trwał przez pięć tysięcy lat po odejściu samego Buddy. Rok 1956 miał stanowić dokładnie połowę tego okresu i po tej dacie będzie następowało stopniowe wygaszenie religii ${ }^{24}$. Oczywiście, tego typu eksplikacje wpisują się w narrację mitu politycznego, opisywaną przez Siewierską-Chmaj, przy czym sam mit służy za usprawiedliwienie najbardziej nawet radykalnych działań25. Poza tym nie sposób wykluczyć po prostu tego, co Spinoza nazwał „ludzkim resentymentem”, w tym przypadku: lęku, zachłanności, plemiennej nienawiści, zazdrości i żądzy władzy, bo i te uczucia o dość uniwersalnym charakterze odegrały swoją rolę w procesie radykalizacji buddyzmu.

Poczucie zagrożenia wspólnoty buddyjskiej przez globalną cywilizację islamu nie ogranicza się wyłącznie do Birmy. Używanie radykalnych haseł religijnych (łącznie z postulowaną ,czystką etniczno-religijną państwa”) celem budowania pozycji politycznej w wydaniu Ashina Wirathu ma również swoje implikacje poza granicami kraju. W roku 2014 uczestniczył on w konferencji „Great Sangha Conference” w Colombo, organizowanej przez partię Bodu Bala Sena, czyli Armię Potęgi Buddyjskiej, coraz bardziej znaczącą organizację polityczną na scenie lankijskiej. Właśnie Sri Lanka jest miejscem, gdzie radykalny polityczny buddyzm rozwinął się w ciągu ostatniej dekady i gdzie widać bardzo ścisłe związki z głoszoną w Birmie koncepcją jedności religijno-etnicznej narodu. Nie budzą obecnie zdziwienia wspólnie organizowane konferencje i hasła dotyczące jedności wspólnoty buddyjskiej, aczkolwiek nie przekłada się to na zinstytucjonalizowane funkcjonowanie żadnej radykalnej „międzynarodówki buddyjskiej”. Pierwszą z liczących się partii, założoną w 2004 roku, była Jathika Helu Urumaya (JHU) - Narodowe Dziedzictwo Syngaleskie, z którego wyrosło radykalne ugrupowanie Bodu Bala Sena (BBS). Za jej ojców założycieli uznaje się mnichów: Kirama Wimalajothi i Galagoda Aththe Gnanasara. Generalnie JHU w sposób dość otwarty promuje jedność syngaleskiego buddyzmu z syngaleską tożsamością mieszkańców, co bliskie jest filozofii głoszonej przez Wirathu. Należy podkreślić, że w roku 2004 JHU zdobyła 9 z 225 miejsc w parlamencie i tę datę uznaje się za oficjalne zaangażowanie się mnichów buddyjskich w krajową politykę ${ }^{26} \mathrm{O}$ ich poparcie starał się w 2005 roku Mahinda Rajapaksa, który okazał się zwycięzcą wyborów prezydenckich i późniejszym długoletnim liderem politycznym Sri Lanki. Jego wizja tworzenia unitarnego państwa tylko częściowo pokrywa się z ideologią radykalnych buddystów. W roku 2009 Rajapaksa ostatecznie pokonał organizację Tygrysów Tamilskich, LTTE (Liberation Tigers of Tamil Eelam), doprowadzając do rozbicia ich infrastruktury militarnej na półwyspie Dżafna i śmierci lidera - Velupillai Prabhakarana. Koszty ostatnich

${ }^{24}$ Kyaw San Wai, Myanmar's Religious Violence: A Buddhist ,Siege Mentality” at Work, Feb 2014, http://reliefweb.int/report/myanmar/myanmar-s-religious-violence-buddhist-siege-mentality-work [dostęp: 11.12.2016]. Warto dodać w tym kontekście, że wskaźnik rozrodczości w Birmie jest rzeczywiście niski i wynosi zaledwie 2,23 (2011), czyli niewiele ponad poziom reprodukcji prostej $(2,1)$. Jest on zresztą niższy w porównaniu z innymi państwami tej części kontynentu. Zob. „Population and Development Review", The Population Council, Inc. 33 (3), s. 453-478.

${ }_{25}$ Por. A. Siewierska-Chmaj, Mity w polityce. Funkcje i mechanizmy aktualizacji, Warszawa 2016.

${ }^{26}$ Dane za oficjalnym raportem na temat wyborów parlamentarnych na Sri Lance w 2004 roku: http://www.slelections.gov.lk/pdf/Preference2004GE.pdf [dostęp: 20.10.2015]. 
tygodni działań wojennych zostały uznane za dramatycznie wysokie, zwłaszcza jeżeli chodzi o liczbę zabitych i rannych - i to głównie po stronie tamilskiej. Według raportu ONZ, opublikowanego w 2011 roku i sygnowanego przez sekretarza generalnego Ban Ki-Moona, śmierć w ostatniej fazie walk poniosło około 40 tysięcy osób, przede wszystkim cywilów ${ }^{27}$. Oskarżenia ze strony organizacji międzynarodowych oraz państw członkowskich Unii Europejskiej o dyskryminację mniejszości tamilskiej zmusiły Rajapaksę do formułowania polityki „,pojednania narodowego” i podkreślania równości dwóch głównych grup etnicznych: Syngalezów i Tamilów ${ }^{28}$. Naprzemienne używanie w publicznych wystąpieniach dwóch języków, stopniowe włączanie polityków tamilskich do administracji ogólnokrajowej czy podkreślanie wspólnej tradycji koegzystencji w jednym państwie stanowiły rdzeń jego polityki wewnętrznej, a to z kolei budziło sprzeciw radykalnych ugrupowań buddyjskich. Realizacja polityki pojednania po kilkudziesięcioletniej wojnie domowej jest z zasady procesem długotrwałym, zwłaszcza że Sri Lanka to państwo o złożonej kompozycji religijno-etnicznej. Faktycznie wśród Syngalezów nie ma prawdopodobnie ani jednego wyznawcy hinduizmu, który reprezentują niemal w stu procentach członkowie mniejszości tamilskiej, i podobnie żaden Tamil nie jest nominalnie buddystą. Z kolei obydwie grupy etniczne obecne są w wyznaniach mniejszościowych: chrześcijaństwie i islamie, które postrzegane bywają przez ugrupowania radykalne jako nielankijskie. Rajapaksa, starający się o podtrzymanie dobrych relacji z BBS w trosce o zapewnienie sobie poparcia skrajnie prawicowych wyborców syngaleskich, nie akceptuje działań, które mogą doprowadzić do destabilizacji państwa. Stąd też jego apele o powstrzymanie się od przemocy w realizacji celów politycznych i utrzymywanie pewnego oficjalnego dystansu w stosunku do ideologii jedności etniczno-religijnej, nawet jeżeli prywatnie z nią sympatyzuje ${ }^{29}$.

\section{Kształtowanie tożsamości syngalesko-buddyjskiej. Ewolucja pojęć sinhalatvy/buddhalatvy i ich relacja wobec politycznej filozofii hindutvy}

Polityczne zaangażowanie mnichów nie stanowi jakiegoś novum w historii Sri Lanki, jeszcze w czasach Imperium Brytyjskiego buddyjscy mnisi byli częścią tego, co obecnie definiuje się jako ruch ,społeczeństwa obywatelskiego”, który w sposób zdecydowany, ale bez stosowania przemocy, występował na rzecz społeczności

${ }^{27}$ Za oficjalnym raportem ONZ: Report of the Secretary General's Panel of Experts on Accountability in Sri Lanka, 31 March 2011. Całość wraz z aneksami liczy 196 stron. Raport jest dostępny na oficjalnej stronie ONZ: http://www.un.org/News/dh/infocus/Sri_Lanka/POE_Report_Full.pdf [dostęp: 14.07.2014].

28 Wojna domowa na Sri Lance ma także swój dramatyczny wymiar literacki. W języku polskim opublikowano niewielką liczbę pozycji, wśród nich: F. Harrison, Do dziś liczymy zabitych. Nieznana wojna w Sri Lance, tłum. H. Pustuła-Lewicka, Wołowiec 2015.

29 Por. N. Wickramasinghe, Sri Lanka in the Modern Age: A History, Oxford 2014, zwłaszcza rozdział: Mahinda Rajapaksa's Ascendance to Power. W 2015 r. Rajapaksa przegrał wybory prezydenckie, a jego następcą został Maithripala Sirisena. Nadal pełni jednak funkcję posła do parlamentu i uznawany jest za jednego z czołowych polityków w państwie. 
syngaleskiej i zachowania tożsamości buddyjskiej kraju. Nie oznaczało to wówczas wyłączenia poza nawias polityczny pozostałych wspólnot etniczno-religijnych. Sytuacja uległa zmianie w okresie po uzyskaniu niepodległości. Spory ideologiczne, toczone na wielu poziomach, podzieliły ówczesne ugrupowania oraz organizacje o charakterze obywatelskim, które wspólnie budowały swoją tożsamość na opozycji wobec Brytyjczyków. Przykładowo, ideologia wąsko pojmowanego nacjonalizmu propagowana była przez Zjednoczony Front Mnichów (Jathika Bhikku Peramuna), który za główne cele obrał dogłębną reformę systemu edukacji, w dużej mierze nadzorowanej przez wspólnotę chrześcijańską (syngalesko-tamilską), oraz przyznanie syngaleskiemu statusu jedynego języka oficjalnego, co naturalnie doprowadziłoby do izolacji mniejszości tamilskiej. Zdecydowany protest Tamilów skłonił rządzącą koalicję do sygnowania w 1957 roku tak zwanego Paktu Bandaranaike-Chelvanayakam, gwarantującego mniejszości tamilskiej ograniczoną autonomię w zakresie kultury, języka czy religii hinduistycznej ${ }^{30}$. Ten polityczny manewr, zainicjowany przez premiera Bandaranaike z socjalistycznej Partii Wolności (Freedom Party), spotkał się jednak z gwałtownym oporem działaczy Zjednoczonego Frontu Mnichów, któremu przewodniczył opat klasztoru Radża Maha Wihara w Kelaniji - Buddharakhita. Oficjalnie oskarżono go o podżeganie do zabójstwa premiera Bandaranaike, który został zamordowany w 1959 roku przez radykalnego buddyjskiego mnicha. Wyrok sądowy na opata (kara śmierci zamieniona ostatecznie na dożywocie) nie był jednak w stanie wyrugować radykalizmu Jathika Bhikku Peramuna z życia politycznego Sri Lanki. Faktycznie nasilił się w okresie wojny domowej, kiedy najbardziej ekstremistycznie nastawieni mnisi utworzyli pragmatyczną koalicję z tak zwanym Frontem Syngalezów (Sinhala Peramuna). Trzeba jednak podkreślić, że koalicja miała bardzo ograniczoną rolę polityczną i skupiała się głównie na propagowaniu radykalnych treści wśród wiernych. Jej hasła zostały przejęte następnie przez Bodu Bala Sena, której pozycja i wpływy na lokalnej scenie politycznej były już nieporównanie większe ${ }^{31}$.

Artur Karp w swojej analizie fenomenu buddyzmu politycznego na Sri Lance zwraca uwagę na pewne elementy historycznego i kulturowego przekazu, które mogą służyć jako inspiracja do działań stricte politycznych, i to nierzadko w wersji radykalnej. Istotną funkcję pełni tutaj Mahawansa, czyli „Wielki Rodowód”, opisujący dzieje kraju od VI wieku przed Chrystusem do IV wieku po Chrystusie. Moralny dylemat i postępowanie cejlońskiego króla Dutthagamaniego (II wiek przed Chrystusem), który staje do walki z tamilskim przeciwnikiem - królem Elarą, mogą być interpretowane przez każdego lidera wspólnoty buddyjskiej jako pewien ponadczasowy wzorzec planowanych i podejmowanych działan. Karp pisze:

Panowanie Widżajów musi trwać, choć to Elara cieszył się powszechnym szacunkiem i opinią sprawiedliwego władcy. Autor kroniki przekazuje pogląd, że „królewska przemoc”, nawet jeśli przybiera skrajne formy, może zostać odkupiona przez obdarow(yw)anie wspólnoty mniszej. W swych rozważaniach kronikarz (buddyjski mnich Naman) wybiega jednak poza rolę

${ }^{30}$ Por. K. Sivathamby, Being a Tamil and Sri Lankan, zwłaszcza rozdział Sri Lankan Tamil Identity, Colombo 2006.

${ }^{31}$ Por. The Sri Lanka Reader, History, Culture, Politics, J.C. Holt (red.), Durham-London 2011. 
historyka, przedstawia bowiem wykładnię niezbędnego związku buddyjskości z człowieczeństwem, wykładnię uzasadniającą dehumanizację niebuddyjskiego wroga ${ }^{32}$.

Taka interpretacja jest naturalnie przydatna w propagowaniu polityki tożsamości religijno-etnicznej, aczkolwiek historyczny kontekst będzie decydował o możliwościach lub ograniczeniach jej stosowania ${ }^{33}$. Wybrany fragment $\mathrm{z}$ uświęconego tradycją dzieła może zawsze służyć jako pretekst do stosowania przemocy - i to niezależnie od całościowego przesłania tej lub innej religii. Ostateczna decyzja na temat wykładni, jak możemy wnioskować na podstawie analizy wydarzeń, zależy od indywidualnego interpretatora, jak również od gotowości wiernych do przyjęcia takiej właśnie radykalnej interpretacji oraz od historycznego momentu, w którym ona następuje.

Z kolei dużo bliższa współczesności i dość pragmatyczna koncepcja Angariki Dharmapali (zm. 1933) pozwoliła na sprecyzowanie idei narodu odwołującej się do uniwersalnej kombinacji więzów etnicznych oraz wyznawanej religii. Sam Dharmapala podkreślał nierozerwalny związek kultury syngaleskiej z miejscową wersją buddyzmu, ale w żaden sposób nie nawoływał do stosowania przemocy w walce politycznej, wówczas toczonej przeciw Brytyjczykom. Brutalizacja działań politycznych nastąpiła dużo później. Artur Karp wspomina o ewolucji samej idei Dharmapali, która zaowocowała pojawieniem się dwóch istotnych pojęć: sinhalatva (syngaleskość) oraz buddhatatva (buddyjskość) ${ }^{34}$. Obydwa mają fundamentalne znaczenie w kontekście propagowania przez Syngalezów polityczno-kulturowej tożsamości na Sri Lance. Przywodzą też na myśl szczegółowo opracowaną koncepcję hindutvy - hinduskości, która stanowi ideologiczny kościec wielu partii i ugrupowań lokowanych na indyjskiej prawicy. Jej twórcą był Vinayak Damodar Savarkar (zm. 1966), bramin z Maharasztry, bojownik walki o niepodległość Indii, ale także zdecydowany przeciwnik ideowy Mahatmy Gandhiego. Savarkar postrzegał hinduizm nie tyle w kategoriach przesłania metafizycznego, ile jako cywilizację tworzącą fundamenty kulturowo-prawne dla państwa i budującą stopniowo tożsamość polityczno-kulturową jego wiernych. Hindutva, co istotne w tym kontekście, obejmowała nie tylko wyznawców hinduizmu, lecz także buddyzmu, dżinizmu i sikhizmu, a więc religii wywodzących się z subkontynentu indyjskiego. Hindutva, podobnie jak sinhalatva/buddhatatva, jest oczywiście ideologią nastawioną na społeczny ekskluzywizm, który z zasady prowadzi najpierw do izolacji wspólnot mniejszościowych, a następnie do konfliktów etnicznych i wyznaniowych w wielokulturowym i wieloreligijnym państwie ${ }^{35}$. Zwolennicy obydwóch ideologii

${ }^{32}$ A. Karp, Relikwia Buddy w grocie włóczni - buddyjskie troski Sri Lanki [w:] Religia w konfliktach etnicznych we wspótczesnym świecie, A. Szabaciuk, D. Wybranowski, R. Zenderowski (red.), Lublin 2016, s. 408.

${ }^{33}$ Radykalna interpretacja tożsamości lankijskiej w wydaniu syngaleskim zderza się w takiej sytuacji z nie mniej radykalną interpretacją tożsamości tamilskiej. W konsekwencji dochodzi do krwawego konfliktu, który jest częścią „polityki tożsamościowej” (identity politics). Szczegółowa analiza, $\mathrm{z}$ uwzględnieniem roli tamilskiego lidera Prabhakarana [w:] S.M.R. Narayan, Inside an Elusive Mind. Prabhakaran, Colombo 2008.

${ }^{34}$ A. Karp, op.cit., s. 398.

${ }^{35}$ Por. W.D. Savarkar, Samagra Savarkar Wangmaya, Puna 1964. Na temat ideologii Savarkara i jej społecznego odbioru por. S. Deshpande, Contemporary India. A Sociological View, New Delhi 2003. Kwestię ideologicznej ewolucji hindutvy ciekawie analizuje T. Gerlach, Indie w świadomości Indusów, 
nie odżegnują się od stosowania przemocy zarówno w stosunku do innowierców, jak i wobec przeciwników ideowych, nominalnie zaliczanych do własnej wspólnoty etniczno-wyznaniowej. Nie powinno zatem dziwić, że Bodu Bala Sena w swojej warstwie ideowej oraz w działaniu politycznym przypomina radykalną partię Shiv Sena, założoną przez Bal Thackeraya w Mumbaju w 1966 roku. Jej fundament ideowy stanowi polityczna filozofia hindutvy, zaś sama partia ma bardzo silną pozycję w stanie Maharasztra i udziela wsparcia rządzącej w Indiach Bharatiya Janata Party ${ }^{36}$. Trudno wykluczyć bezpośrednią czy wręcz personalną inspirację ideologiczną i organizacyjną ze strony Shiv Seny, szczególnie że jej polityczna i społeczna aktywność była przedmiotem zainteresowania partii ogólnokrajowych w Indiach, Nepalu i na Sri Lance.

\section{Radykalizacja działań buddyjskich ugrupowań politycznych}

Ideowe pokrewieństwo generuje podobne działania w sferze społecznej i politycznej. BBS zaangażowana jest w pomoc wyznawcom buddyzmu na Bliskim Wschodzie, gdzie są zatrudnieni w krajach Zatoki Perskiej, protestuje przeciw atakom na mniejszość buddyjską w Bangladeszu, ale przede wszystkim stawia ostre żądania na forum krajowym. Podczas wiecu w marcu 2013 roku na przedmieściach Colombo ostrze krytyki skierowała przeciw wyznawcom islamu i chrześcijaństwa, uznając że Sri Lanka powinna stać się buddyjskim krajem Syngalezów, a nie państwem wieloreligijnym i wielokulturowym. W publicznych wystąpieniach członkowie BBS apelowali o wprowadzenie zakazu sprzedaży żywności halal, co byłoby praktycznym krokiem w realizacji polityki monokultury buddyjsko-syngaleskiej.

W ciągu ostatniej pięciolatki nastąpiła radykalizacja działań BBS, która już otwarcie stosuje przemoc, z rzadka powstrzymywaną przez struktury państwa. Przykładowo, w czerwcu 2014 roku w miejscowościach Aluthgama, Beruwela i Dharga mnisi z BBS zorganizowali wiec, podczas którego zaatakowali werbalnie mniejszość muzułmańską, przy czym następnego dnia rozpoczęto już atak fizyczny, paląc domy, sklepy, bijąc mieszkańców. Dane na temat ofiar są dość zróżnicowane, najczęściej podaje się, że zamordowano 4 osoby i zidentyfikowano 50 rannych, przy czym wszyscy poszkodowani to wyznawcy islamu ${ }^{37}$. Wydarzenia relacjonowano dość szeroko w mediach, nie tylko lankijskich, lecz także światowych, zwłaszcza że publicystyczny slogan „,buddyjskiego terroru”, propagowany przez magazyn „Time”, przyciągnął uwagę agencji informacyjnych głównego nurtu w Europie, Stanach Zjednoczonych

\footnotetext{
Wrocław 1988. Z kolei szczegółową prezentację politycznej filozofii hindutvy przedstawiam w swojej publikacji: O pęknięciu wewnątrz cywilizacji. Ideologiczny spór między modernistami a fundamentalistami w islamie $i$ hinduizmie $w$ XX i na początku XXI wieku, Warszawa 2005.

${ }^{36}$ Por. Hindu Nationalism, A Reader, Ch. Jaffrelot (red.), Ranikhet 2009, zwłaszcza rozdział: The Maharashtrian Crucible of Hindu Nationalism, s. 14-16.

${ }^{37}$ Za informacjami przekazanymi przez TV Al-Jazeera, In Picture, Sri Lanka hit by religious riots, 18 June 2014, http://www.aljazeera.com/indepth/inpictures/2014/06/pictures-sri-lanka-hit-religio2014617112053394816.html [dostęp: 09.10.2015].
} 
i na Bliskim Wschodzie. Warto dodać, że wspomniany już numer „Time” objęto zakazem rozpowszechniania zarówno w Birmie, jak i na Sri Lance, aczkolwiek na wyspie wkrótce pojawiły się inkryminowane artykuły w wydaniach internetowych ${ }^{38}$.

Ideologia i działania Bodu Bala Sena spotykają się z powszechną krytyką, i to nie tylko - co zrozumiałe - wśród przedstawicieli mniejszości muzułmańskiej czy międzynarodowych organizacji, takich jak International Crisis Group, ale też wśród polityków lankijskich i społeczności mnichów. Parlamentarzysta i były szef dyplomacji Sri Lanki Mangala Samaraweera publicznie porównał BBS do ugrupowania talibów, oskarżając ją o „szerzenie ekstremizmu i komunalistycznej nienawiści w stosunku do muzułmanów"39. Podobne, ostre sformułowania kolejnych reprezentantów lankijskiego establishmentu zostały wielokrotnie upublicznione, niemniej jednak miały one dość ograniczony wpływ na postępowanie oraz ideologię BBS. Azjatycka Komisja Praw Człowieka (Asian Human Rights Commission) wystąpiła z podobnymi słowami oskarżenia BBS jako organizacji ekstremistycznej, która zagraża stabilizacji państwa, ale słowa krytyki skierowała także do władz Sri Lanki, które - zdaniem komisji - lekceważą zagrożenie i nie są skłonne do ograniczania działalności ekstremistów $^{40}$. W takiej sytuacji warto postawić roboczą tezę, że Jathika Helu Urumaya i Bodu Bala Sena wraz ze swoją radykalną ideologią nie staną się w ciągu najbliższej dekady istotną częścią głównego nurtu polityki, niemniej jednak ich mało skomplikowane przesłanie może stopniowo kształtować narodową tożsamość wybranych grup Syngalezów, a w sytuacjach konfliktów etnicznych i wyznaniowych uzyska zdecydowane poparcie najważniejszych aktorów sceny politycznej na Sri Lance zwłaszcza gdy zbiegnie się w czasie z radykalizacją nastrojów wśród mniejszości tamilskiej.

Fenomen JHU, BBS czy 969 nie jest naturalnie czymś wyjątkowym na współczesnej mapie świata. Proces budowania tożsamości opartej na wspólnocie etniczno-językowo-wyznaniowej, często z użyciem przemocy, był, jest i prawdopodobnie nadal będzie dość powszechny nie tylko w Azji, lecz także w Europie czy na Bliskim Wschodzie. Tym, co wyraźnie odróżnia wspomniane ugrupowania od podobnych istniejących w różnych miejscach świata, jest odwołanie się do religii, którą postrzega się (szczególnie w świecie euroatlantyckim) jako apolityczną, i całkowicie niekompatybilną ideowo z zasadą stosowania przemocy. Jak się jednak okazuje, wielowiekowa interpretacja dharmy nie stanowi przeszkody w procesie redefiniowania buddyzmu i nadawania mu charakteru religii politycznej. Ma stanowić specyficzny fundament, na którym budowana jest tożsamość narodowa według kryterium

${ }^{38}$ Pełny przedruk tekstu, który został objęty zakazem rozpowszechniania w Birmie i na Sri Lance, pojawił się w „Colombo Telegraph” zaledwie kilka dni po ukazaniu się wersji papierowej „Time”, https:// www.colombotelegraph.com/index.php/full-text-of-the-banned-time-story-the-face-of-buddhist-terror/ [dostęp: 20.10.2015].

${ }^{39}$ Wypowiedzi za: H. Bandara, BBSO challenges Mangala equating it to a terrorist outfit, „The Sunday Times" (Sri Lanka), 17 February 2013, http://www.sundaytimes.lk/130217/news/bbso-challenges-mangala-equating-it-to-a-terrorist-outfit-33653.html [dostęp: 17.09.2015].

${ }^{40}$ Za oficjalnym komunikatem Asian Human Rights Commission: Sri Lanka: A monk leads mob violence at Maligawatta with the connivance of the police, 3 March 2013, http://www.humanrights.asia/ news/ahrc-news/AHRC-STM-049-2013/ [dostęp: 13.09.2015]. 
etniczno-wyznaniowego. Sprzeciw wobec takiej zmitologizowanej politycznie definicji buddyzmu prawdopodobnie nie powstrzyma jego dalszej transformacji, szczególnie w epoce bardzo dynamicznych przemian społecznych w całej Azji i coraz większej akceptacji dla zasad Realpolitik.

\section{Buddyzm jako instrument polityki zagranicznej. Kongregacja Buddyjska i jej udział w strategii rządu Republiki Indii}

Zjawisko polityzacji buddyzmu ma wiele wymiarów, zaś stojące w sprzeczności interpretacje dharmy (na przykład non-violence vs. violence policy) mają przełożenie na spory o możliwą rolę buddyzmu jako czynnika łączącego, a zarazem dzielącego społeczności na poziomie lokalnym i międzynarodowym. Szanse na upolitycznienie religii i wykorzystanie jej w relacjach międzynarodowych zostały dostrzeżone przez rosnącą liczbę graczy na globalnej szachownicy, za bardzo prawdopodobne możemy uznać, że proces ten będzie się nasilał w ciągu najbliższych dekad. Buddyzm nie jest tutaj wyjątkiem i jego rola $\mathrm{w}$ tym kontekście może być w przyszłości dość znacząca. Jest to szczególnie widoczne w stosunkach bilateralnych między dwoma najludniejszymi państwami świata: Chinami i Indiami, których obszary współpracy są tak samo duże jak obszary możliwego konfliktu. Nie powinno zatem dziwić, że zarówno New Delhi, jak i Pekin rozwijają swoje wielopoziomowe strategie oddziaływania i budowania pozycji w Azji, w których elementy soft power muszą mieć swoją silną i uzasadnioną tradycją pozycję. Realizacja kolejnych punktów strategii będzie mieć z kolei wpływ na regionalny układ sojuszy w Azji Południowo-Wschodniej.

W dniach 27-30 listopada 2011 roku zorganizowano w Delhi i Kalkucie Globalną Kongregację Buddyjską, której jednym z najważniejszych uczestników był Dalajlama XIV. Charakter uroczystości, relacjonowanych we wszystkich mediach ogólnokrajowych, został oprotestowany przez Pekin, który odwołał zaplanowaną wcześniej 15. rundę rozmów bilateralnych indyjsko-chińskich na temat delimitacji spornych części granicy między obydwoma państwami ${ }^{41}$.

Inauguracja Globalnej Kongregacji Buddyjskiej (GBC, Global Buddhist Congregation), której główna siedziba ma znajdować się w Indiach, odbyła się z pełną akceptacją, a nawet częściowym wsparciem rządu centralnego, aczkolwiek wsparcie to miało charakter półoficjalny, bez uczestnictwa ówczesnych liderów: prezydent Pratibhy Patil czy premiera Manmohana Singha. Mimo silnego sprzeciwu Chin i gróźb co do możliwych sankcji politycznych, przedstawiciel rządu Republiki Indii, gubernator Bengalu Zachodniego Mayankote K. Narayanan spotkał się podczas imprez towarzyszących GBC z Dalajlamą. Spotkanie odbyło się w Kalkucie i poświęcono je oficjalnie dziełu Matki Teresy. Sam przywódca duchowy Tybetu unikał

${ }^{41}$ Informacje o wydarzeniu ukazały się we wszystkich najważniejszych mediach angielskoi hindijęzycznych. Zamieściły je również najważniejsze buddyjskie stowarzyszenia w Indiach, na przykład Ashoka Mission: http://www.asokamission.com/app/global-buddhist-congregation, z kolei wystąpienie Dalajlamy podczas Kongregacji zostało umieszczone pod adresem: https://www.youtube. com/watch?v=mOlUb_DNykA [dostęp: 19.08.2015]. 
jakichkolwiek komentarzy politycznych, podkreślając kilkakrotnie, że przekazał już władzę polityczną wybranemu rządowi na uchodźstwie w marcu 2011 roku. W wykładach głoszonych podczas Kongregacji Dalajlama koncentrował się wyłącznie na tematyce religijnej, unikając jakichkolwiek sformułowań, które mogłyby mieć znaczenie bądź interpretację polityczną. Analitycy i komentatorzy indyjscy podkreślali wartość systemu politycznego Indii vis-à-vis obiekcji wysuwanych przez Chiny:

Chiny odmawiają wyraźnie uznania i akceptacji prostego faktu, że Indie są demokracją, gdzie jednostki, i to zarówno obywatele państwa, jak i cudzoziemcy, mają zagwarantowane prawa i swobody polityczne, chyba że złamią obowiązujące przepisy. Indie są państwem suwerennym, które samo decyduje, co leży w jego interesie. Dlatego też Dalajlama ma pełne prawo do podróżowania wewnątrz Indii, bez jakichkolwiek ograniczeń. Na jego korzyść działa też to, że jest bardzo ostrożny w swoich wypowiedziach i działaniu. Nigdy nie postawił Indii w niezręcznej sytuacji, ani też nie przyczynił się do jakiegokolwiek [politycznego - P.K.] dyskomfortu New Delhi ${ }^{42}$.

Przyjęcie formuły publicznego low profile przez Dalajlamę nie oznaczało jednak, iż charakter całości imprezy był wyłącznie religijny. Sam wyraźnie zaakcentował tezę, że inkarnacja jego następcy nastąpi poza Tybetem, co w praktyce uniemożliwiłoby Pekinowi narzucenie wiarygodnego następcy odłamowi Gelug (jedna z czterech szkół buddyzmu tybetańskiego), na którego czele stoi obecny Dalajlama. Co jednak niezwykle istotne, jak podkreślił Tempa Tsering, oficjalny przedstawiciel przywódcy duchowego Tybetu w New Delhi, to fakt, że ,religijne przesłanie Dalajlamy zostało przedstawione wśród wyjątkowo szacownego grona buddystów reprezentujących najbardziej wpływowe wspólnoty buddyjskie w całej Azji”³. Organizatorzy GBC zadbali, aby w uroczystościach wzięli udział patriarchowie najważniejszych odłamów buddyjskich z Bhutanu, Sri Lanki, Kambodży, Birmy, Tajlandii, ale też przedstawiciele z Rosji, Nepalu, Mongolii, Tajwanu, Hongkongu czy Korei Południowej. Pięciu spośród nich przysługuje tytuł „Jego Świątobliwości” (podobnie jak Dalajlamie), dziesięciu tytuł „Jego Eminencji” (tak w wersji anglojęzycznej). Obecny był również 17 Gyalwang Karmapa, zwierzchnik odłamu Kagyu buddyzmu tybetańskiego. Łącznie w czterodniowym zgromadzeniu wzięło udział około 900 mnichów i mniszek, którzy razem ze świeckimi delegatami reprezentowali niemal 40 państw, w tym Chiny kontynentalne (22 liderów wspólnot buddyjskich). Zdaniem Tseringa, było to - jeżeli uwzględnić obecność hierarchii i zasięg ich wpływu w świecie buddyjskim - najważniejsze zgromadzenie buddystów od roku 1956, czyli od uroczystości 2500-lecia parinirwany Buddy, obchodzonego na Sri Lance. Niewykluczone, że w perspektywie najbliższego dziesięciolecia Indie za pomocą GBC będą starały się budować sieć nieformalnych relacji ze wspólnotami buddyjskimi w Wietnamie, Birmie, na Sri Lance czy w Nepalu, a więc z krajami, które odgrywają niezwykle istotną rolę we współzawodnictwie indyjsko-chińskim w Azji. Warto dodać w tym kontekście, że Chiny na początku drugiej dekady XXI wieku coraz bardziej kontestowały

42 Cytat za: „News behind the News”, 5 December 2011, New Delhi.

${ }^{43}$ Opinia przedstawiona podczas nieformalnego spotkania z przedstawicielami dyplomatycznymi wybranych państw członkowskich Unii Europejskiej w grudniu 2011 r. Tam też dodatkowe informacje na temat Kongregacji. 
inicjatywy Indii w stosunku do wybranych krajów azjatyckich: chodziło tu między innymi o wspólne przedsięwzięcie eksploracji dwóch bloków wietnamskich na Morzu Południowochińskim przez indyjską ONGC Videsh Ltd. czy o stopniowe przełamywanie impasu Indii z Birmą, co było możliwe dzięki wizycie w New Delhi w październiku 2011 roku prezydenta Thein Seina, który mówił o wspólnych korzeniach religijnych i kulturowych obydwóch państw. Kolejne elementy współzawodnictwa z perspektywy indyjskiej dotyczyły blokowania chińskich planów wspierania buddyzmu w Nepalu czy rozwoju polityki pomocowej dla Sri Lanki, szczególnie w stosunku do mniejszości tamilskiej. Rosnące zaangażowanie Indii jest rezultatem coraz aktywniejszego stosowania polityki „Look East Policy”, która pośrednio stara się redukować wpływy chińskie w Azji Południowo-Wschodniej. Indie realizują ją na wielu poziomach, zaś stosowanie religijnego soft power stwarza następne pole rywalizacji z Pekinem ${ }^{44}$. Dla efektywnego wdrażania ustaleń Kongregacji uczestnicy GBC podjęli decyzję o założeniu w 2012 roku stałej organizacji, Międzynarodowej Konfederacji Buddyjskiej (International Buddhist Confederation), która ma skupiać przedstawicieli najważniejszych wspólnot buddyjskich z całego świata.

Kolejnym etapem promocji buddyzmu jako jednego z narzędzi kreowania polityki zagranicznej była decyzja rządu i parlamentu indyjskiego o zaproszeniu ówczesnego premiera Bhutanu Lyonchhen Jigmi Y. Thinleya do wygłoszenia 20 grudnia 2011 roku wykładu w ramach tak zwanego Hiren Mukerjee Memorial Annual Parliamentary Lecture na temat filozofii buddyjskiej w praktyce: Gross National Happiness: A Holistic Paradigm For Sustainable Well-being. Wykład ten - wygłaszany raz do roku w parlamencie w obecności wiceprezydenta, premiera, posłów i dyplomatów - jest uznawany za najbardziej prestiżowy, jeśli chodzi o znaczenie polityczne, oraz wskazuje na priorytety i możliwe działania samego rządu. Premier Y. Thinley podkreślił, że Indie powinny stać się dla wielu krajów azjatyckich liderem, „który dzięki swojej wiarygodności wynikającej z wielowiekowej kultury i zasadom demokracji jest w stanie zbudować silną sieć sojuszników"45. Sformułowania premiera Bhutanu dobrze wpisywały się w przesłanie Global Buddhist Congregation o ulokowaniu swojej siedziby w Indiach. Pozwoliło to New Delhi kontrolować przekaz ideologiczny Kongregacji, a także wzmacniać autorytet kraju jako wiarygodnego „opiekuna wspólnot buddyjskich” na całym świecie, nie wyłączając samych Chin. Intensyfikacja działań politycznych z wykorzystaniem karty buddyjskiej została zainaugurowana podczas rządów Kongresu Narodowego, ale o ich kontynuacji zadecydowała koalicja Narodowego Sojuszu Demokratycznego (National Democratic

${ }^{44}$ Por. rozdział: D. Markey, Developing India's Foreign Policy „Software” [w:] India's Foreign Policy, A Reader, K.P. Bajpai, H.V. Panti (red.), Oxford 2013, s. 188 i n. „Look East Policy” formalnie stanowiła część programu polityki zagranicznej koalicji United Progressive Alliance aż do 2014 r., czyli do wyborów przegranych przez partię Kongresu, i właśnie w ramach tej polityki realizowano pomysły dotyczące ,politycznej internacjonalizacji buddyzmu”. BJP po objęciu władzy zainaugurowała własną wersję pod hasłem „Act East Policy”, która ma w założeniu zwiększać dynamikę i zakres działań państwa na wschodzie kontynentu.

${ }^{45} \mathrm{Na}$ podstawie oficjalnych dokumentów Lok Sabha dystrybuowanych wśród personelu dyplomatycznego podczas wykładu: Hiren Mukerjee Memorial Annual Parliamentary Lecture: „, Gross National Happiness: A Holistic Paradigm For Sustainable Well-being" by HE Lyonchhen Jigmi Y. Thinley, Prime Minister of Bhutan, Lok Sabha, 20 December 2011. 
Alliance), w której liderem jest Indyjska Partia Ludowa, BJP. Po zdecydowanym zwycięstwie w wyborach parlamentarnych w 2014 roku premier Narendra Modi podkreślił zaangażowanie Indii w politykę bliskiego sąsiedztwa, przy czym istotną rolę ma odgrywać w niej „promowanie wspólnej tradycji, która łączy poszczególne państwa regionu". Znaczącym gestem premiera Indii była jego pierwsza oficjalna wizyta zagraniczna złożona w Bhutanie, który publicznie deklaruje obronę tradycyjnych wartości buddyjskich ${ }^{46}$.

\section{Buddyzm jako element chińskiej polityki zagranicznej}

Instytucjonalne zaangażowanie rządu Indii w promowanie polityki wspólnej tradycji ma bardzo konkretne implikacje w relacjach dwustronnych. Zwraca uwagę podtrzymywana do dziś deklaracja International Buddhist Congregation, że do jej głównych zadań należy między innymi ochrona buddyjskiego dziedzictwa w Indiach i Nepalu, przy czym w tym drugim przypadku chodzi o miejsce szczególne, czyli Lumbini w południowej części kraju, gdzie według tradycji miał narodzić się Budda. Taka decyzja prawdopodobnie wzbudziła irytację Pekinu, jako że ambitne plany rozwoju ośrodka buddyjskiego w Lumbini (akademickie centrum badań nad buddyzmem, hostele dla pielgrzymów, rozbudowa całej infrastruktury transportowej, słowem - stworzenie „Mekki dla buddystów”, i to w odległości 7 kilometrów od granicy z Indiami) zostały już wcześniej przedstawione przez organizację NGO, Asia Pacific Exchange and Cooperation Foundation, z siedzibą w Hongkongu, którą - zdaniem analityków indyjskich - czynnie wspierają władze ChRL. Propozycja, szacowana prawdopodobnie przesadnie przez „The Economist” na 3 miliardy dolarów, została jednak odrzucona przez władze nepalskie, najprawdopodobniej pod silną polityczną presją New Delhi, które uznało, że formalnie neutralne plany chińskie zagrażają strategicznym interesom Indii ${ }^{47}$.

Wspólne zainteresowanie promocją tradycji buddyjskiej może jednak służyć inicjatywom, które ocieplają relacje bilateralne. Dość mocno reklamowanym w mediach indyjskich chińskim planem w obszarze buddyjskiej soft power jest wsparcie finansowe i merytoryczne rekonstrukcji Uniwersytetu Nalanda (istniał od V do XII wieku n.e. na terenie dzisiejszego Biharu), na który Pekin zadeklarował oficjalnie sumę około 1 miliarda dolarów. W październiku 2011 roku delegacja chińska, na czele z ówczesnym wiceministrem spraw zagranicznych Zhang Zhijun spotkała się $z$ indyjskim laureatem Nagrody Nobla, prof. Amartya Senem, przewodniczącym tak zwanego Nalanda University Mentor Group, odpowiednika rady nadzorczej, aby przedyskutować możliwości realizacji projektu. W oficjalnym komunikacie podkreślono nawiązanie do tradycji historycznej wizyty w Nalandzie mnicha Xuangzanga z czasów dynastii Tang (VII wiek n.e.), który przyczynił się do rozkwitu buddyzmu w Chinach, jak również „wymieniono opinię na temat odbudowy Uniwersytetu

\footnotetext{
${ }^{46}$ Szerzej na temat relacji indyjsko-bhutańskich z perspektywy historycznej: M. Rajput, Indo-Bhutan Relations through Prism of History, New Delhi 2011.

${ }^{47}$ Por. A Bizarre Project in Nepal. At Buddha's Birthplace, „The Economist”, 20 August 2011.
} 
Nalanda oraz współpracy w dziedzinie kultury i edukacji między Indiami a Chinami”. Miesiąc później ambasador ChRL w Indiach, Zhang Yan, przekazał czek na sumę miliona dolarów, która ma być przeznaczona na chińską bibliotekę uniwersytecką. Projekt jest de facto w fazie wstępnej, chociaż formalnie uczelnia ma status prawny, wybranego rektora, zaś stan Bihar wydzielił obszar 180 ha na całość przyszłego kampusu akademickiego. Oficjalnie uczelnia zaczęła funkcjonować w 2014 roku, ale ukończenie kampusu przewidywane jest na rok 2020. Pekin gotowy jest nadal partycypować w kosztach realizacji projektu, który ma szansę na promowanie w skali międzynarodowej głównych zasad buddyjskiej dharmy ${ }^{48}$.

Zaangażowanie w politykę „,buddyjskiej soft power”, która pozwoliłaby z jednej strony na wzmacnianie wpływów politycznych Chin w Azji, z drugiej na kontrolowanie przekazu religijnego u siebie w kraju, znalazło swoje instytucjonalne przełożenie w funkcjonowaniu World Buddhist Forum (WBF), oficjalnie założonego w 2006 roku. W czasie pierwszej kongregacji, zorganizowanej w miastach Hangzhou i Zhoushan, pojawiło się ponad tysiąc mnichów i ekspertów zajmujących się buddyzmem, którzy reprezentowali 37 krajów. WBF ma jednak dość ograniczoną autonomię, co widać w konstrukcji składu osobowego głównych jego mentorów; całości przewodniczył mnich Yi Cheng z Buddhist Association of China, funkcję zastępcy pełnił Losang Jigmê Tubdain Qoigyi Nyima, opat klasztoru Labrang i również członek Buddhist Association of China, pozostali reprezentowali Chiny kontynentalne oraz Hongkong i Tajwan. ChRL próbowała wówczas rozegrać według własnego scenariusza tak zwaną kartę tybetańską, promując publicznie Gyaincain Norbu, czyli namaszczonego przez Pekin jedenastego Panczenlamę, de facto nieuznawanego przez wspólnotę buddyjską nie tylko w Tybecie, lecz także w większości państw regionu. Według informacji agencji Reuters i BBC zdecydowana większość mnichów buddyjskich starała się unikać publicznego kontaktu z Panczenlamą, co sprawiło, że plan stopniowego przejmowania kontroli przez Pekin nad poszczególnymi odłamami buddyzmu tybetańskiego i nadania temu procesowi legitymacji wyznaniowej nie odniósł - przynajmniej w początkowej fazie - znaczącego sukcesu ${ }^{49}$. Kolejna kongregacja WBF odbyła się w Wuxi (Chiny kontynentalne) oraz na Tajwanie w Tajpej w 2009 roku. Uczestniczyło w nim około 1700 przedstawicieli z ponad 50 krajów, aczkolwiek nadreprezentację posiadały wspólnoty z samych Chin, Hongkongu i Tajwanu. W ceremonii otwarcia brał również udział wspierany przez Pekin Panczenlama, który swoje przemówienie wygłosił nie po chińsku czy tybetańsku, ale bardzo starannie po angielsku, co - według chińskich mediów - zostało ciepło przyjęte przez przedstawicieli wspólnot buddyjskich spoza kręgu chińskojęzycznego. ChRL jest przygotowana na finansowanie tego typu przedsięwzięć. Samo zbudowanie supernowoczesnego

${ }^{48}$ Oficjalne dane na temat całości projektu Nalanda University dostępne on-line: http://www.nalandauniv.edu.in/ [dostęp: 20.10.2015].

${ }^{49}$ Informacje za: China hosts first Buddhism forum, BBC News, 13 April 2006, http://news.bbc. co.uk/2/hi/asia-pacific/4905140.stm [dostęp: 28.10.2015]. Oczywiście, informacje na temat WBF dostępne są na wielu stronach internetowych publikowanych oficjalnie w ChRL. Negatywne komentarze i opinie na temat możliwych kontaktów z Panczenlamą zostały wyrażone także przez przedstawicieli administracji tybetańskiej na uchodźctwie podczas spotkania z dyplomatami PCz UE na spotkaniu w grudniu 2011 r. w New Delhi. 
centrum Ling Shan Fan Gong, wyłącznie do goszczenia drugiej kongregacji WBF, kosztowało, według różnych źródeł, między 200 a 300 mln dolarów ${ }^{50}$. Kolejne zgromadzenia World Buddhist Forum w 2012 w Hongkongu i 2015 roku w Wuxi, prowincja Jiangsu, zostały przedstawione przez Pekin jako organizacyjny i propagandowy sukces, który rzekomo jest doceniany i akceptowany przez większość wiernych na całym świecie ${ }^{51}$. Ogromne zaangażowanie polityczne, finansowe i organizacyjne Chin w promowanie WBF jako głównego na świecie forum buddyjskiego teraz, a także w przyszłości będzie się cieszyło uznaniem całej wspólnoty buddyjskiej, i to niezależnie od afiliacji jej członków z poszczególnymi odłamami buddyzmu. Nie więc dziwnego, że sama idea powołania Globalnej Kongregacji Buddyjskiej (GBC), jej skala, zasięg geograficzno-polityczny, lokalizacja głównego centrum w Indiach, wreszcie jej bliskie relacje z XIV Dalajlamą będą budziły głębokie niezadowolenie w Pekinie, czy nawet obawy o szanse rozwijania przez New Delhi sieci kontaktów w całej Azji (ze specjalnym uwzględnieniem Azji Południowo-Wschodniej) i budowania swojego wizerunku jako państwa opiekuna buddyzmu, ,strażnika ziemi świętej". Chociaż trudno obecnie z pełnym przekonaniem stawiać tezę o wydzielonej strategii poświęconej dyplomacji buddyjskiej, która stosowana byłaby przez New Delhi, to w praktyce GBC, a następnie IBC stają się znaczącymi instrumentami politycznej presji Indii w wielostronnych relacjach z Chinami, także dzięki możliwościom wywierania wpływu w krajach o tradycji buddyjskiej, nie wyłączając terytorium dzisiejszej ChRL razem z Tybetem.

\section{Uwarunkowania i ograniczenia przy wykorzystaniu „karty buddyjskiej" w polityce zagranicznej}

Mamy tutaj do czynienia z pewnym paradoksem, jako że o ile w Chinach, według różnych źródeł, do buddyzmu przyznaje się około $20 \%$ ludności (mimo postulowanego ateizmu wśród członków KPCh), o tyle w samych Indiach buddyzm odgrywa obecnie znikomą rolę jako religia per se, mimo rozlicznych prób jego promocji i popularyzowania metod medytacji przez samego Dalajlamę bądź takie instytucje jak Ashoka Mission, Mahabodhi Society czy Vipassana Movement. Liczbę jego rodzimych wyznawców szacuje się na 1-2\% całości populacji, zaś wśród nich dużą część stanowią tak zwani dalici (niedotykalni), którzy masowo nawracali się na wiarę buddyjską w połowie lat pięćdziesiątych XX wieku z inspiracji swojego lidera, Bhimrao Ramji Ambedkara. W ostatniej dekadzie ceremonie buddyjskie organizowane były na dużą skalę przy wsparciu Mayawati, ówczesnej premier największego liczebnie stanu Uttar Pradesh, która wywodzi się z klasy dalitów. Jednak po jej porażce wyborczej w 2012 roku ich liczbę znacznie ograniczono. Warto wspomnieć, że hinduizm bardzo wcześnie przejął dużą część nauk buddyjskich, niejako wchłaniając

50 Por. Y. Yiyun, A Buddhist palace fit for the gods, „The China Daily”, 15 October 2010, http://www.chinadaily.com.cn/china/2010expo/2010-10/15/content_11414118.htm [dostęp: 08.11.2015].

51 Por. oficjalne informacje i fotografie na temat czwartego Forum organizowanego przez agencję Xinhua: http://news.xinhuanet.com/english/photo/2015-10/24/c_134746459.htm [dostęp: 11.09.2015]. 
i przetwarzając tradycję Buddy, stąd też jego atrakcyjność w Indiach była i jest nadal dość ograniczona. Jednocześnie polityczna rola buddyzmu jest dla New Delhi nie do przecenienia. Indie coraz częściej wykorzystują fakt, że są „ziemią świętą” dla wszystkich wyznawców buddyzmu na świecie, a także to, iż XIV Dalajlama, postrzegany jako niemal śmiertelny wróg Pekinu, jest jego współczesną ikoną. Posługiwanie się w grze politycznej kartą religijną to zjawisko w Indiach dość powszechne, aczkolwiek rządząca przez dziesięciolecia partia Indyjski Kongres Narodowy starała się przez lata unikać jednoznacznych afiliacji z konkretnym wyznaniem. To zaczyna się jednak zmieniać, zwłaszcza że BJP otwarcie nawiązuje do ideologii hindutvy, czyli politycznego hinduizmu. Srijana Mitra Das w swoim artykule na temat użyteczności religii w procesie budowania poparcia politycznego przywołuje słowa Mahatmy Gandhiego, ojca założyciela Republiki Indii. Gandhi sformułował często cytowaną później myśl, że „Ci, którzy powiadają, iż religia nie ma nic wspólnego z polityką, zaprawdę nie wiedzą, czym jest religia". Sam stosował z dużym sukcesem bogatą symbolikę religijną w całej działalności politycznej. Mitra Das, przywołując filozofię Mahatmy, bardzo postuluje konieczność odwołania się do dziedzictwa religijnego Indii w realizowaniu polityki przez ówczesny Kongres ${ }^{52}$. Faktycznie, jak można wnioskować, Indie rozpoczynają kolejny etap gry z Chinami, wykorzystując rosnącą w Azji i w samych Chinach rolę buddyzmu, w tym również w jego tybetańską odmianę. Ma to naturalnie charakter półoficjalny, także w wydaniu BJP, zainteresowanej bardziej niż Kongres promowaniem tradycji religijnej, i stanowi element współzawodnictwa ideologicznego, nakładającego się na rywalizację w dziedzinie militarnej, ekonomicznej czy politycznej. Niewykluczone, że zaostrzy to konfrontację, bowiem w dziedzinie ideologicznej kompromisy są dużo mniej prawdopodobne niż w sferze politycznej czy ekonomicznej ${ }^{53}$.

Możliwa w bliskiej przyszłości międzynarodowa polityzacja buddyzmu, jeżeli chodzi o współzawodnictwo Indii z Chinami, może przywodzić na myśl znane już przykłady wykorzystania przekonań religijnych w kreowaniu zmian w strukturze państw czy w relacjach międzynarodowych: chodzi tu między innymi o polityczną rolę islamu w procesie budowania współczesnej tożsamości Arabów, Irańczyków czy Pakistańczyków, rolę chrześcijaństwa (szczególnie rzymskiego katolicyzmu) w walce z państwem autorytarnym w Ameryce Łacińskiej czy w Polsce, wreszcie rolę hinduizmu w przypadku implementacji politycznej idei wspólnoty hindusów - i to niezależnie od kraju ich zamieszkania. Każdy z tych przykładów ma swoje odrębne uwarunkowania kulturowe, odmienną formułę interpretacji politycznej w relacjach z państwem czy wreszcie - inną siłę oddziaływania, łączy je jednak jedno, a mianowicie to, że religia udowodniła, iż posiada w sobie ogromny społeczno-polityczny potencjał do wykorzystania, szczególnie w czasach kryzysu ekonomicznego i rosnącej frustracji społeczeństwa, które odrzuca dotychczasowy sposób funkcjonowania państwa. W przypadku buddyzmu trudno jednoznacznie ocenić, w jaki sposób

52 S.M. Das, Religion and Politics, „The Times of India”, 12 December 2011.

${ }^{53}$ Por. pozycję na temat stopniowej modyfikacji współczesnej polityki zagranicznej Indii oraz stosowania dyplomatycznej soft power: S. Tharoor, Pax Indica. India and the World of the 21st Century, New Delhi 2012. 
zarówno Indie, jak i Chiny mogą ów potencjał wykorzystać, niemniej jednak warto zwrócić uwagę na różnicę środków do dyspozycji obydwóch państw. Chiny mają przede wszystkim potężne zasoby finansowe i niewielką wiarygodność (legitimacy), Indie zaś dużą (ale nie całkowitą) wiarygodność i nieporównywalnie mniejsze środki finansowe ${ }^{54}$. Akurat $\mathrm{w}$ przypadku stosowania narzędzi religijnych w polityce międzynarodowej Indie wydają się znajdować w dużo lepszej sytuacji, a przynajmniej nie gorszej niż Chiny. Dyplomacja w służbie nowej azjatyckiej Realpolitik zyskała w ten sposób poręczne narzędzie do skutecznego działania.

\section{Zakończenie i wnioski}

Radykalizacja polityczna buddyzmu w wybranych państwach i używanie go w procesie kształtowania tożsamości narodowej z zastosowaniem przemocy jest fenomenem świeżej daty, aczkolwiek związek między buddyzmem a polityką liczy kilka tysięcy lat, zaś jedną z najlepszych tego egzemplifikacji są rządy cesarza Aśoki (III w. p.n.e.) po jego konwersji na buddyzm. Podobne zabarwienie polityczne miały rządy kolejnych dalajlamów w Tybecie, którzy nie ograniczali swych funkcji do dziedziny ściśle religijnej, ale sprawowali rzeczywistą władzę w konkretnych realiach historycznych. Niemniej jednak trudno było wówczas mówić o pełnym i usprawiedliwionym zaangażowaniu wspólnoty mnichów (sangha) w świat bezpośredniej polityki; ta najczęściej była wyłączną domeną świeckich. Zdaniem Paula Harrisona, elementy znaczącej polityzacji buddyzmu były widoczne już na początku XX wieku, a nawet wiek wcześniej,

[...] gdy stopniowo rola wspólnoty zakonnej (sangha) była redefiniowana wraz z powstaniem nowych form buddyzmu. Część wyznawców uznała, że właściwym obowiązkiem członków wspólnoty zakonnej jest zaangażowanie się w społeczną działalność, aby polepszyć los ludu, podczas gdy inni uznali, że ich obowiązkiem jest całkowite powstrzymanie się od takich działan ${ }^{55}$.

Sposób i metody uczestnictwa w życiu politycznym mogły być przedmiotem dyskusji, chociaż mało kto odrzucał doktrynę non-violence, kojarzoną niezmiennie $\mathrm{z}$ buddyzmem. Rozwój tendencji fundamentalistycznych w chrześcijaństwie, islamie i hinduizmie w XX stuleciu nie pozostał prawdopodobnie bez wpływu na postrzeganie roli religii w państwach o tradycji buddyjskiej. Modernizacja środków komunikacji, łatwy przepływ informacji, a tym samym wzrost zainteresowania losem współwyznawców w innych częściach świata, musiały przyczynić się do kolejnej redefinicji zasad funkcjonowania współczesnego buddyzmu, zwłaszcza w jego formie monastycznej. Aktywność polityczna buddyjskich mnichów na Sri Lance czy w Birmie nie różni się zbytnio od aktywności wybranych członków szyickiego ruhanijat, sunnickich alimów czy hinduistycznych swamich. Różnica, tym razem w ujęciu

${ }^{54}$ Temat ten pośrednio jest poruszany w kontekście relacji chińsko-tybetańskich [w:] J. Bayer, W. Dziak, Tybet. Szkice z dziejów chińsko-tybetańskich, Warszawa 2015.

${ }_{55}$ P. Harrison, Buddhism and Politics [w:] Inteview for D.I.Y. Dharma, http://www.diydharma.org/ buddhism-and-politics-paul-harrison [dostęp: 23.09.2015]. 
historycznym i dotyczącym samej sanghy, dotyczy problematyki użycia przemocy. W interpretacji birmańskiej organizacji 969 oraz lankijskiej Bodu Bala Sena przemoc w stosunku do innowierców jest akceptowana i sporadycznie stosowana. Brak jednak szczegółowo opracowanej ideologii przemocy (jak chociażby w przypadku hinduistycznej hindutvy), która miałaby umocowanie ideowe w nauce buddyzmu. Jej uzasadnienie polityczne nawiązuje do znanych gdzie indziej sloganów o zachowaniu tożsamości wyznaniowo-etnicznej i eliminowaniu wpływu grup mniejszościowych, co samo w sobie generuje konflikt ${ }^{56}$. Mało też prawdopodobne, aby taka ideologia, ze szczegółowym uzasadnieniem zasad stosowania przemocy w buddyzmie, kiedykolwiek powstała. Niemniej jednak w sferze praktycznej przemoc będzie stosowana, i to niezależnie od głosów krytyki krajowej czy międzynarodowej. Sytuacje kryzysowe, w których rywalizują poszczególne grupy etniczne, wyznaniowe czy językowe, po prostu implikują możliwość odwołania się do przemocy, zaś poręczność prostych sloganów, nawet bez wyrafinowanej doktryny ideologicznej, wystarcza do trwałego podtrzymywania konfliktu. Najnowszy etap polityzacji buddyzmu w kontekście birmańskim i lankijskim będzie charakteryzował się zatem coraz większą dawką przemocy, której eksplikacja i usprawiedliwienie nie będą odnosiły się bezpośrednio do dharmy, ale do istniejących od wieków naturalnych podziałów wyznaniowych i etnicznych, obecnie coraz częściej uznawanych przez radykalnie nastawionych członków wspólnoty za zagrożenie dla stabilności państwa i tradycji buddyjskiej.

$\mathrm{Z}$ kolei instytucjonalna polityzacja buddyzmu $\mathrm{w}$ relacjach międzynarodowych w żaden sposób nie wygląda na fenomen całkowicie współczesny. Buddyzm i jego tradycja monastyczna mają z zasady charakter uniwersalistyczny, dlatego wspieranie misji religijnych buddyzmu poza granicami państwa stanowiło dla wielu władców (w tym wspomnianego już cesarza Aśoki) istotny element dyplomacji, a tym samym część strategii wzmacniania swojej potęgi politycznej w regionie. W przypadku Indii i Chin mamy jednak do czynienia z sytuacją dość wyjątkową. Obydwa państwa nie mają charakteru wyznaniowego, są de iure republikami świeckimi, które teoretycznie nie powinny propagować haseł religijnych, zwłaszcza w polityce międzynarodowej. Co więcej, buddyzm jest religią mniejszości - i to zarówno w Chinach, jak i w Indiach, aczkolwiek może być interpretowany jako istotny element kulturowej tożsamości ich mieszkańców. Te uwarunkowania nie przeszkadzają jednak w realizacji celów polityki zagranicznej, która dzięki upolitycznieniu na skalę międzynarodową religii, uznawanej dotychczas za apolityczną, może doprowadzić do pozyskania nowych sojuszników na regionalnej szachownicy. Globalna rywalizacja dwóch azjatyckich gigantów, której intensywność wzrosła w ciągu ostatniej dekady, zmusza do sięgania do rezerwuaru nowych, niewykorzystywanych dotychczas instrumentów ${ }^{57}$. Nie sposób obecnie określić, jaka będzie skuteczność Indii i Chin w procesie wykorzystania buddyzmu jako elementu strategii promowania własnych interesów w Azji, ale możemy przynajmniej założyć, że jego rola w relacjach wielostronnych może być

${ }^{56} \mathrm{Na}$ temat konfliktów z mniejszością chrześcijańską w krajach o tradycji buddyjskiej por. P. Hattaway, Peoples of the Buddhist World, Pasadena 2004.

${ }^{57} \mathrm{Na}$ temat złożonej rywalizacji oraz współpracy Indii i Chin w Azji Południowo-Wschodniej por. K.J. Pankaj, India and China in Southeast Asia. Competition or Cooperation?, New Delhi 2013. 
większa niż w ubiegłym stuleciu. Wątpliwe się wydaje, aby z takiej internacjonalizacji buddyzmu był rad sam Gautama Budda. Podobnie jak i z pomysłów niektórych mnichów ze Sri Lanki oraz Birmy.

\section{Bibliografia}

A Bizarre Project in Nepal. At Buddha's Birthplace, „The Economist”, $20^{\text {th }}$ August 2011.

Bayer J., Dziak W., Tybet. Szkice z dziejów chińsko-tybetańskich, Warszawa 2015.

Beech H., The Face of Buddhist Terror, „Time”, 1 July 2013.

Benn J.S., Burning for the Buddha: Self-immolation in Chinese Buddhism, Honolulu 2007,

Charney M.W., A History of Modern Burma, Cambridge 2009.

Dalai Lama, Freedom in Exile, The Autobiography of the Dalai Lama of Tibet, London 2002.

Deshpande S., Contemporary India. A Sociological View, New Delhi 2003.

Gerlach T., Indie w świadomości Indusów, Wrocław 1988.

Freeing Tibet. 50 Years of Struggle, Resilience, and Hope, J.B. Roberts, F.A. Roberts (red.), New Delhi 2011.

Harris I., Buddhism, Politics and Nationalism [w:] Buddhism in the Modern World, D. McMahan (red.), New York 2012.

Harrison F., Do dziś liczymy zabitych. Nieznana wojna w Sri Lance, thum. Hanna Pustuła-Lewicka, Wołowiec 2015.

Hattaway P., Peoples of the Buddhist World, Pasadena 2004.

Hindu Nationalism, A Reader, Ch. Jaffrelot (red.), Ranikhet 2009.

Hiren Mukerjee Memorial Annual Parliamentary Lecture: „Gross National Happiness: A Holistic Paradigm For Sustainable Well-being” by HE Lyonchhen Jigmi Y. Thinley, Prime Minister of Bhutan, Lok Sabha, 20 December 2011.

Hodal K., Buddhist Monk uses Racism and Rumours to Spread Hatred in Burma, „The Guardian”, 18 April 2013.

Hpo Hlaing, Mingyi U Iaw, Rajadhammasangaha, transl. L.E. Bagshawe from the biographical preface and edition made by Maung Htin (U Htin Fatt), Rangoon 1979.

Huntington S., Trzecia fala demokratyzacji, tłum. A. Dziurdzik, Warszawa 2009.

Jha P.K., India and China in Southeast Asia. Competition or Cooperation?, New Delhi 2013.

Karp A., Relikwia Buddy w grocie włóczni - buddyjskie troski Sri Lanki [w:] Religia w konfliktach etnicznych we współczesnym świecie, A. Szabaciuk, D. Wybranowski, R. Zenderowski (red.), Lublin 2016.

Kawanami H., Buddhism and the Political Process, Basingstoke 2014.

Kłodkowski P., O pęknięciu wewnątrz cywilizacji. Ideologiczny spór między modernistami a fundamentalistami w islamie $i$ hinduizmie w XX i na poczatku XXI wieku, Warszawa 2005.

Kłodkowski P., Geopolitics and the Issue of the Broken National Identity in Nepal, „Politeja” 2016, nr 40.

Linossier R., The Mythology of Buddhism in India [w:] Asiatic Mythology, New Delhi-Madras 1994.

Mendelson M.E., Sangha and State in Burma: A Study of Monastic Sectarianism and Leadership, Ithaca, NY, 1975.

Markey D., Developing India's Foreign Policy „Software” [w:] India's Foreign Policy, A Reader, K.P. Bajpai, H.V. Panti (red.), Oxford 2013.

Mitra S.D., Religion and Politics, „The Times of India”, 12 December 2011.

Mohanty B., Foreign Policy of India in the 21st Century, New Delhi 2012.

Myint-U T., The Making of Modern Burma, Cambridge 2001. 
Narayan S.M.R., Inside an Elusive Mind. Prabhakaran, Colombo 2008.

Pankaj K.J., India and China in Southeast Asia. Competition or Cooperation?, New Delhi 2013.

Rajput M., Indo-Bhutan Relations through Prism of History, New Delhi 2011.

Sarkisyanz M., Buddhist Backgrounds of the Burmese Revolution, The Hague 1965.

Savarkar W.D., Samagra Savarkar Wangmaya, Puna 1964.

Siewierska-Chmaj A., Mit polityczny jako fundament ideologii. Próba analizy [w:] Przekazy polityki, A. Siewierska-Chmaj (red.), Kraków-Rzeszów-Zamość 2009.

Siewierska-Chmaj A., Mity w polityce. Funkcje i mechanizmy aktualizacji, Warszawa 2016.

Simpson A., Language and National Identity in Asia, Oxford 2007.

Singh A., International Relations, Jaipur 2012.

Sivathamby K., Being a Tamil and Sri Lankan, Colombo 2006.

Smith D.E., Religion and Politics in Burma, Princeton, NJ, 1965.

Spiro M.E., Buddhism and Society: A Great Tradition and its Burmese Vicissitudes, Berkeley 1982.

Tharoor S., Pax Indica. India and the World of the 21st Century, New Delhi 2012.

The Lotus Sutra, A Contemporary Translation of a Buddhist Classic, transl. and introduction

G. Reeves [w:] Previous Lives of Medicine King Bodhisattva, New York 2014.

The Prototype of Auto-cremation as Political Protest - The Death of Thich Quang Duc [w:] Sacred Suicide, J.L. Lewis, C.M. Cusack (red.), Burlington 2014.

The Sri Lanka Reader, History, Culture, Politics, J.C. Holt (red.), Durham-London 2011.

Thinley L.J.Y., Prime Minister of Bhutan, ,, Gross National Happiness: A Holistic Paradigm For

Sustainable Well-being”, Hiren Mukerjee Memorial Annual Parliamentary Lecture, Lok Sabha,

20 December 2011.

Turner A., Saving Buddhism: The Impermanence of Religion in Colonial Burma, Honolulu 2014.

Wickramasinghe N., Sri Lanka in the Modern Age: A History, Oxford 2014.

Woeser T., Tibet on Fire: Self-immolations against Chinese Rule, New York 2016.

Wolf R., The Popular Encyclopedia of World Religions, Eugene 2007.

\section{Źródla internetowe}

Al-Jazeera TV, In Picture, Sri Lanka hit by religious riots, 18 June 2014, http://www.aljazeera.com/ indepth/inpictures/2014/06/pictures-sri-lanka-hit-religio-2014617112053394816.html [dostęp: 9.10.2015].

Ashin Wirathu, Facebook, https://www.facebook.com/AshinWirathu/ [dostęp: 19.08.2015].

Ashoka Mission, Global Buddhist Congregation, http://www.asokamission.com/app/global-buddhist-congregation [dostęp: 19.08.2015].

Asian Human Rights Commission: Sri Lanka: A monk leads mob violence at Maligawatta with the connivance of the police, 3 March 2013, http://www.humanrights.asia/news/ahrc-news/AHRC-STM-049-2013/ [dostęp: 13.09.2015].

Bandara H., BBSO challenges Mangala equating it to a terrorist outfit, „The Sunday Times” (Sri Lanka), 17 February 2013, http://www.sundaytimes.lk/130217/news/bbso-challengesmangala-equating-it-to-a-terrorist-outfit-33653.html [dostęp: 17.09.2015].

The Banned Time Story: The Face of Buddhist Terror, „Colombo Telegraph”, https://www.colombotelegraph.com/index.php/full-text-of-the-banned-time-story-the-face-of-buddhist-terror/ [dostęp: 20.10.2015].

Bodu Bala Sena, http://www.bodubalasena.org/ [dostęp: 20.10.2015].

Buddhism and Self-immolation, ,The Economist”, http://www.economist.com/blogs/erasmus/2013/ 03/buddhism-and-self-immolation [dostęp: 22.11.2015].

China hosts first Buddhism forum, BBC News, 13 April 2006, http://news.bbc.co.uk/2/hi/asia-pacific/4905140.stm [dostęp: 28.10.2015].

The Dalai Lama Address to the Global Buddhist Congregation, https:/www.youtube.com/watch?$\mathrm{v}=$ mOlUb_DNykA [dostęp: 19.08.2015]. 
Harrison P., Buddhism and Politics [w:] Interview for D.I.Y. Dharma, http://www.diydharma.org/ buddhism-and-politics-paul-harrison [dostęp: 23.09.2015].

Human Rights Watch Reports „All You Can Do is Pray”. Crimes against Humanity and Ethnic Cleansing of Rohingya Muslims in Burma's Arakan State, 22 April 2013, https://www.hrw.org/ report/2013/04/22/all-you-can-do-pray/crimes-against-humanity-and-ethnic-cleansing-rohingya-muslims [dostęp: 7.10.2015].

Kyaw San Wai, Myanmar's Religious Violence: A Buddhist „Siege Mentality” at Work, Feb 2014, http://reliefweb.int/report/myanmar/myanmar-s-religious-violence-buddhist-siege-mentality-work [dostęp: 11.12.2016].

Nalanda University, http://www.nalandauniv.edu.in/ [dostęp: 20.10.2015].

Report of the Secretary General's Panel of Experts on Accountability in Sri Lanka, 31 March 2011, http://www.un.org/News/dh/infocus/Sri_Lanka/POE_Report_Full.pdf,

Shiv Sena Party, http://shivsena.org/m/ [dostęp: 14.07.2014].

Sri Lanka Election Results, http://www.slelections.gov.lk/pdf/Preference2004GE.pdf [dostęp: 20.10.2015].

Xinhua Agency: 4th World Buddhist Forum held in E China, http://news.xinhuanet.com/english/ photo/2015-10/24/c_134746459.htm [dostęp: 11.09.2015].

Yang Yiyun, A Buddhist palace fit for the gods, „The China Daily”, 15 October 2010, http://www. chinadaily.com.cn/china/2010expo/2010-10/15/content_11414118.htm [dostęp: 08.11.2015].

Walton M.J. Burmese Buddhist Politics, Oxford Handbooks Online, Scholarly Research Reviews, http://www.oxfordhandbooks.com/view/10.1093/oxfordhb/9780199935420.001.0001/oxford-hb-9780199935420-e-21\#oxfordhb-9780199935420-e-21-bibItem-25 [dostęp: 17.12.2016]. 